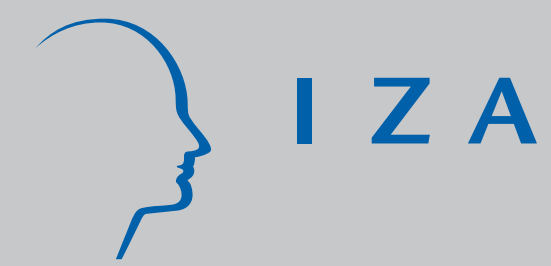

IZA DP No. 574

Understanding Interhousehold Transfers in a Transition Economy: Evidence from Russia

Randall Kuhn

Steven Stillman

September 2002 


\title{
Understanding Interhousehold Transfers in a Transition Economy: Evidence from Russia
}

\author{
Randall Kuhn \\ University of Colorado, Boulder \\ Steven Stillman \\ New Zealand Department of Labour and IZA Bonn \\ Discussion Paper No. 574 \\ September 2002 \\ IZA \\ P.O. Box 7240 \\ D-53072 Bonn \\ Germany \\ Tel.: +49-228-3894-0 \\ Fax: +49-228-3894-210 \\ Email: iza@iza.org
}

This Discussion Paper is issued within the framework of IZA's research area Labor Markets in Transition Countries. Any opinions expressed here are those of the author(s) and not those of the institute. Research disseminated by IZA may include views on policy, but the institute itself takes no institutional policy positions.

The Institute for the Study of Labor (IZA) in Bonn is a local and virtual international research center and a place of communication between science, politics and business. IZA is an independent, nonprofit limited liability company (Gesellschaft mit beschränkter Haftung) supported by the Deutsche Post AG. The center is associated with the University of Bonn and offers a stimulating research environment through its research networks, research support, and visitors and doctoral programs. IZA engages in (i) original and internationally competitive research in all fields of labor economics, (ii) development of policy concepts, and (iii) dissemination of research results and concepts to the interested public. The current research program deals with (1) mobility and flexibility of labor, (2) internationalization of labor markets, (3) welfare state and labor market, (4) labor markets in transition countries, (5) the future of labor, (6) evaluation of labor market policies and projects and (7) general labor economics.

IZA Discussion Papers often represent preliminary work and are circulated to encourage discussion. Citation of such a paper should account for its provisional character. A revised version may be available on the IZA website (www.iza.org) or directly from the author. 
IZA Discussion Paper No. 574

September 2002

\section{ABSTRACT \\ Understanding Interhousehold Transfers in a Transition Economy: Evidence from Russia*}

This paper uses data from the Russian Longitudinal Monitoring Survey to describe and model the determinants of interhousehold transfers. Russian households have experienced large reductions in income during the post-Soviet transition period, with a particularly severe decline occurring in the fall of 1998. Sharply declining fertility, increasing mortality, and past demographic catastrophes has left a population which is both young (few elderly) and old (one of the oldest working-age populations in the world). Informal networks in Russia are likely to take on distinctive characteristics as the country's economic institutions are underdeveloped and there is a very limited social safety net, while household structure closely resembles that found in much wealthier countries.

Although it is often assumed that the elderly in Russia are a highly vulnerable economic group, we actually find that transfers flow strongly from the elderly to their adult children, whom are typically in the early part of the life-course (i.e. in school, starting to work, or recently married). This is especially true for the elderly in rural areas. While households with higher longer-term resources receive on net more transfers, we also find strong evidence that transfers respond to economic needs (i.e. transitory fluctuations in resources).

JEL Classification: D12, J14, O12, P36

Keywords: interhousehold transfers, aging, household structure, Russia, transition economies

Corresponding author:

Steven Stillman

Labour Market Policy Group

New Zealand Department of Labour

56 The Terrace - PO Box 3705

Wellington

New Zealand

Tel: +64-4-915-4742

Email: steven.stillman@Impg.dol.govt.nz

\footnotetext{
* Steven Stillman gratefully acknowledges financial support from the National Institute on Child Health and Human Development. We thank Sabrina Wulff Pabilonia and Rebecca Rainof for thoughtful comments.
} 


\section{I) Introduction}

In its current stage of economic development Russia provides a unique setting for the study of informal exchange networks. While it is neither a developed nor a developing country, it shares many characteristics of both. Russia's economy is highly industrialized and urbanized, yet its formal economic institutions are poorly developed. Its limited public transfer system is heavily indebted, yet it remains an important source of income for many Russian households. Declining fertility, increasing mortality, and past demographic catastrophes have left Russia's population disproportionately middle-aged, a demographic structure unique to transition economies. The determinants and value of such transfers may impact the well-being of vulnerable or dependent populations and may affect broader patterns of individual and societal investment.

Becker's theory of social interaction demonstrates how private transfers, typically conducted within the family, can generate human capital investment, insurance, and old-age support in the absence of well-developed public transfer systems or capital markets. ${ }^{\text {i }}$ Familial feelings of altruism can explain the tendency for parents to invest in their children's education, for children to support their parents in old age, and for family members with higher incomes to support those with lower incomes. ${ }^{\text {ii }}$ Yet these behaviors can also be explained by self-interested motivations: parents may support children in anticipation of future old-age support, adults may support older parents to encourage their own children to provide future support, and high earners may support those with lower earnings in anticipation of a subsequent reversal of fortunes. ${ }^{\text {iii }}$ Exchange motivations are particularly powerful in explaining transfers conducted outside the domain of the immediate family unit: distant kin, non-kin, or close kin living in separate regions or countries. ${ }^{\text {iv }}$

While altruism and exchange models offer divergent predictions regarding the relationship between public and private transfers, and on the impact of demographic change on transfer patterns, this paper neither presents a formal model of interhousehold transfers in Russia nor 
attempts to distinguish (i.e. test) which model of transfer behavior best fits the evidence that we present. Instead, using rich household survey data from the Russian Longitudinal Monitoring Survey (RLMS), we focus on providing a thorough description of the determinants of interhousehold transfers in Russia, examining both the flow of aggregate transfers and the variety of non-household members with whom transfers are exchanged. An important contribution of our study is that by: (1) carefully controlling for and stratifying our results by household structure, and (2) controlling for both long-term household resources and short-run changes in these resources (taking advantage of the panel nature of our data), we are able to study both lifecourse transfers, from individuals in their peak earning years to their dependents, and concurrent transfers, from individuals with higher incomes to those with lower incomes.

Although it is often assumed that the elderly in Russia are a highly vulnerable economic group, we find that transfers flow strongly from the elderly to their adult children, even after these children form their own families and begin to rear children. While the macro-level flow of transfers moves from older individuals to their adult children, we also find strong evidence that transfers respond to economic need. Households with low levels of long-term resources and those that experience negative short-run shocks to resources receive, on net, greater transfers.

\section{II) Interhousehold Transfers in Developing and Developed Economies}

Research on the relationships between parental investments in children, family change, and oldage support outlines the role of private transfers in generating security and support over the life-

course. ${ }^{\mathrm{v}}$ Studies of rapidly developing economies demonstrate how extensive parental investments in children's human capital are subsequently repaid through old-age transfers. ${ }^{\mathrm{vi}}$ Theoretical and empirical work shows that when life-course transfers are conducted through private channels, parental incentives to invest in children's human capital are enhanced by the 
direct benefit parents receive from highly educated children ${ }^{\text {vii }}$ in contrast, parents receive less direct return from educating their own children when most transfers pass through public channels. ${ }^{\text {viii }}$

Attempts to relate population aging, social change, and economic change to old-age transfer flows have resulted in divergent theoretical predictions and empirical conclusions. Theories of modernization and the declining role of the family suggest that as economies shift from agrarian to modern modes of production, the net flow of life-course transfers shifts from benefiting elders, on net, to benefiting the young. ${ }^{\text {ix }}$ Yet much of our accumulated knowledge suggests that the elderly tend to gain support in aging societies, often at the expense of the youngest cohorts. ${ }^{\mathrm{x}}$ In societies with public pension systems, elderly pensions persist as a policy priority by virtue of the voting power of the elderly themselves, and the desire of working-age voters to preserve future pension benefits in old age. ${ }^{\mathrm{xi}}$ In developing countries, better educated children provide extensive financial support in place of personal care. ${ }^{\text {xii }}$

Research on intra-familial economic diversification develops the role of private transfers, both within and between households, as a source of concurrent economic redistribution. Where capital markets are underdeveloped or do not exist, transfers can replace the functions of credit, insurance, and futures markets as well as those of public social welfare systems. ${ }^{\text {xii }}$ Individuals redistribute income through existing familial relationships, and expand their network of possible transfer partners through marital and fictive kinship relationships as well as participation in migration networks and rotating networks of credit and labor exchange. ${ }^{\text {xiv }}$ However, these transfers may fail to fulfill their prescribed roles efficiently and equitably. Membership in transfer networks may be driven by exchange motivations, excluding individuals and groups who are economically and physically vulnerable, while drawing their membership from pre-existing 
networks of familial, spatial, or linguistic preference. ${ }^{\mathrm{xv}}$

Concurrent exchange also points to a complex set of relationships between public transfers and private ones. ${ }^{\mathrm{xvi}}$ Extensive public transfer activity may not only limit the amount of income that passes through private transfer networks, but it may lead to the dismantling of traditional networks of altruistic familial exchange: social and spatial mobility may increase, family structures may grow more nucleated, and traditional family norms may be undermined by public policy initiatives. ${ }^{\text {xvii }}$ Yet, a significant body of work has demonstrated the important role of concurrent transfer arrangements in the presence of well-developed public transfer systems, both as a continued source of protection against economic shocks, and as a means of effectively redistributing public transfers to other family members. ${ }^{\text {xviii }}$

\section{III) The post-Soviet Russian Context}

Economically, Russia's industrial capacity and human capital base resemble that found in wealthier developed countries, yet its economy is highly dependent on price-volatile commodity exports (prominently, oil, gas, ferrous metals, aluminum, and timber) and households face tremendous economic risk owing to an underdeveloped market infrastructure. Figure 1 displays quarterly changes in Russia's seasonally adjusted real GDP, real dollar-ruble exchange rate, and overall price level from the first quarter of 1994 to the first quarter of $2002{ }^{\text {xix }}$ The Russian economy has seen few quarters of positive growth during the transition period and experienced a major crisis in the fall of 1998, with real GDP declining by between $10-15 \%$ in two consecutive quarters. ${ }^{\mathrm{xx}}$ The economy grew strongly in 1999 and 2000, making up most of the ground lost in 1998. Hyperinflation was common during the early transition period with inflation running between $20-50 \%$ per quarter until the beginning of 1996 . Inflation has been relatively low and stable since then, except during the 1998 crisis. Russia's integration into world markets has also 
seen increasing frequency and magnitude of swings in the value of the ruble.

Demographically, Russia's working-age population is old even by developed world standards, yet it is relatively "unburdened" by old-age dependency due to a pattern of high adult mortality. ${ }^{x x i}$ As shown in figure 2, sharply declining fertility, increasing mortality, and past demographic catastrophes (the two World Wars and the famine of the 1930's) have left a population with a huge gender imbalance (around 85 men per 100 women) and a few very small birth cohorts (in particular, those born during early 1930's, early 1940's, and late 1960's). Sex ratios of around 50 males per 100 females among the over 60 population reflect rapid declines in male life expectancy to 59 years and the large loss of life in WWII.

Socially, Russia's family structure and life-course values remain distinctly European, yet the diminished expectations of both the Cold War and post-Soviet eras have demanded informal support and extended housing arrangements similar to those of less developed countries. Informal support arrangements have perhaps gained prominence in the transitional context, yet many people, particularly those who worked primarily under the Soviet system, continue to depend on formal sources of support such as pensions, housing subsidies and utilities subsidies. Most of these public payment systems have stood in arrears for the bulk of the transitional period. Arrears have often been repaid in an inconsistent or unpredictable fashion. ${ }^{\text {xii }}$

There has thus far been limited work examining interhousehold transfers in Russia during the transition period. The only study that focuses on transfers appears to be the work of Cox, Eser, and Jimenez, which uses data from RLMS collected during the early transition period (1992-1993). ${ }^{\text {xiii }}$ They conclude that interhousehold transfers during this period are large, widespread, related to socioeconomic characteristics, and are targeted at what appear to be vulnerable groups. The higher quality of the later rounds of RLMS allows our paper to go 
beyond their analysis, especially in our ability to look at the response of transfers to long-run differences versus short-run changes in household resources.

\section{IV) Data}

RLMS is an on-going longitudinal household survey of Russia designed and collected by the Carolina Population Center, University of North Carolina, in collaboration with the Russian Academy of Sciences. The data have been collected in two phases which are not comparable. All empirical analyses in this paper use data from phase II which covers 1994 through $2000{ }^{\text {xxiv }}$ The sampling frame for RLMS is a set of dwellings drawn to be representative of the Russian population in the early 1990s. For cost reasons, the survey does not attempt to follow individuals or households who move from the sample dwelling. Instead, any new household member or new household living at the sample dwelling is included in the sample in each wave. The sample will remain representative of the underlying population assuming new entrants are interchangeable with movers. ${ }^{\mathrm{xx}}$

The survey contains a rich array of information on economic, social, demographic and health characteristics of the respondents; their households; and the communities in which they live. This paper makes use of data collected at the individual, household, and site level. ${ }^{\text {xxvi }}$ Specifically, we focus on the relationship between interhousehold transfers and household resources, both measured at the household level for the month prior to interview, while carefully controlling for the characteristics of the environment in which respondents are living, focusing both on household structure and the attributes (age, gender, education, and marital status) of all individuals in the household.

The survey records information on 5,986 households who contribute 19,341 household-year observations during the sample period. We drop 38 households and 228 observations with 
missing data on either household income and/or interhousehold transfers, leaving a sample which includes 1,308 rural households who contribute 4,931 household-year observations and 4,640 urban households who contribute 14,182 household-year observations. ${ }^{\text {xxvii }}$

Table 1 presents summary statistics for all variables used in the paper. ${ }^{\text {xxviii }}$ The first column presents means and standard deviations for the full sample. To provide a sense of the importance of attrition (on observables), the second column includes only the first wave of data that are used in this study (round 5). These respondents provide a representative baseline sample against which the full sample can be compared. The third column presents summary statistics for all rural households and the fourth for all urban households. The differences between the first two columns are very small (although, due to the large sample size, many are significantly different). We conclude that attrition (related to observable characteristics) is not a serious concern in these data ${ }^{x x i x}$ Household structure and the attributes of household members (especially, education) differ a great deal between rural and urban households. For this reason, we present all of our descriptive evidence separately for rural and urban households (and condition on community fixed effects, which includes whether a community is urban, in our regression models). ${ }^{\mathrm{xx}}$

Table 2 summarizes the distribution of household income and interhousehold transfers in the month prior to each interview. There is substantial variation in household income, with income at the $75^{\text {th }}$ percentile approximately four times larger than that at the $25^{\text {th }}$ percentile for both rural and urban households. Transfers make up, on average, $9 \%$ of after-transfer income and $25 \%$ of all households have transfer activity. As shown in the next section, this varies extensively by household structure and life-course position. There are large difference in income between households who are net givers and receivers, with the average net giver household having twice the income of the average net receiver household. 
Table 3 summarizes participation rates, transfer values for households that give/receive transfers, and overall net transfer receipts to/from three different possible targets: (1) the parents of the household respondent; (2) the children of the household respondent; and (3) all other nonhousehold members (including other family, friends, etc.). ${ }^{\mathrm{xxi}}$ In order to clearly establish the path of transfers, we stratify our results by both household structure and life-course position. We first split all households into two groups based on household structure. The first group, which we call 'single generation households', includes all households except those in which: (1) at least one elderly (age >54(F), >59(M)) member lives with more than one adult (age 20-54(F), 2059(M)) member (this mainly includes elderly individuals and couples who live with their married children); or (2) at least one adult member lives with more than one elderly member (this mainly includes adults who still live at home with their elderly parents). ${ }^{\text {xxii }}$ The second group of households we refer to as 'multi-generation households'. Overall, $81 \%$ of rural households and $84 \%$ of urban households are of the single generation variety.

We then break these two groups into a total of seven different household types (four single generation and three multi-generation) based on life-course position. For single generation households the categories are: (1) households where the respondent is younger than 35 (Young Households); (2) households where the respondent is between 35 and 54, and the household has children (Older Households with Children); (3) households where the respondent is between 35 and 54, and the household has no children (Older Households without Children); and (4) households where the respondent is older than 54 (Elderly Households). For multi-generation households the categories are: (1) households where the respondent is younger than 35; (2) households where the respondent is between 35 and 54; and (3) households where the household respondent is older than 54 . 
In general, the transfer activity of the three multi-generation household types bears similarity to households of simpler composition in the same life-course position: multi-generation households with a young respondent look similar to young households, those with an older adult respondent look similar to older households without children in rural areas and to older households with children in urban areas, and those with an elderly respondent look similar to elderly households. Multi-generation households typically have less extensive transfer activity because of the increased likelihood of familial exchange activity occurring within the household, and thus not being captured by the RLMS data. As the absence of intrahousehold transfer data make it difficult to model transfer activity for multi-generation households, we focus only on the single generation households in presenting descriptive results stratified by household type and in our regression analysis later in the paper.

Elderly households have less gross transfer activity than other households, but they have a consistent net outflow of transfers. Urban elderly households received 88 rubles (19\% x 472) and gave 127 (24\% x 520), for a moderate net outflow of 38 rubles. Rural elderly households are twice as likely to give transfers as they are to receive (26\% to $13 \%)$, although the smaller value of transfers given, conditional on giving any (589 vs. 725 rubles), also results in a moderate net outflow (97 received -155 given $=-58$ net). Most transfer activity to/from elderly households involve their children, with flows that favor children in urban (49 received -78 given $=-27$ net) and rural (55 received -116 given $=-59$ net $)$ areas.

Older households without children have a high likelihood of giving transfers and give large amounts in both rural $(24 \% \times 1081=262$ rubles $)$ and urban $(33 \% \times 678=225$ rubles $)$ areas. These households receive limited transfers and thus have the largest outflow of all groups (in rural areas, 72 received -262 given $=-190$ net, in urban area, 150 received -225 given $=-72$ 
net). As is found for the elderly, these large outflows go almost entirely to children. These households largely consist of "empty-nesters", individuals who have not reached retirement age but have no children remaining in the home.

In contrast, older households with children are net receivers of transfers, with rural households receiving, on net, 66 rubles (168 received - 102 given) and urban households 75 rubles (215 received - 140 given). Transfer patterns for these households are complex, with both rural and urban households receiving, on net, positive transfers from parents and from others (quite likely, parents-in-law and older siblings), and negative transfers from non-resident children. The behavior of these households lies between that of the "empty-nesters" described above and the behavior of the young households described next.

Young households are far more likely to receive transfers, receive transfers of greater value, and receive a greater in-flow of transfers than all other household types. In particular, $44 \%$ of all urban young households receive transfers and the mean value of those transfers is 1094 rubles,

resulting in a mean receipt of 484 rubles by these households. While these households also give transfers $(22 \%$ x $488=105$ rubles $)$, they have a net receipt of 382 rubles, while all other urban household types have a net receipt of at most 75 rubles. Rural young households are also very likely to receive transfers, receiving, on average, 304 rubles ( $37 \%$ x 831). As giving from these households is fairly limited ( $13 \%$ x $340=45$ rubles), they average a large net receipt of 257 rubles. For both rural and urban households, transfers flow mainly from the parents of the household respondent and from others, most likely the parents-in-law of the respondent.

\section{V) Regression Results}

Our empirical models attempt to identify the sources of heterogeneity in household transfer activity by looking separately at the determinants of whether households give/receive transfers 
and the determinants of how much they give/receive. For transfer flows in each direction, we estimate a logistic regression model predicting the log-odds of giving/receiving any transfer in terms of a rich set of controls for household resources, the attributes (age, gender, education, and marital status) of all individuals in the household, and community and year fixed effects:

$$
\log \left(\frac{P_{h t}}{1-P_{h t}}\right)=\alpha+\beta Y_{h t}+\delta X_{h t}+\alpha_{t}+\alpha_{c}+\varepsilon_{h t}
$$

where $h$ indexes households, $c$ indexes communities, $t$ indexes time, $P_{h t}$ is the observed likelihood of giving or receiving any transfer, $Y_{h t}$ is $\log$ household income, and $X_{i t}$ is a vector of household characteristics including number of child, adult, and elderly household members by gender; age of household members at each life-stage (age of the youngest child, average age of all adults, and age of the oldest elder); marital status of the household (either married, never married / divorced, or widowed), ${ }^{\text {xxiii }}$ and number of household members in different educational categories (currently enrolled in primary or secondary school, currently enrolled in vocational school or university, completed general secondary education (equivalent to US high school), has a university diploma, and has a professional course diploma (for example, bookkeeping)). The $\alpha$ terms represent the overall intercept, year fixed effects, and community fixed effects, respectively, and $\varepsilon_{h t}$ is an idiosyncratic standard logistic error term with mean zero and variance one. ${ }^{\text {xxiv }}$

We also estimate, for each direction of transfer flow, an OLS regression model where the dependent variable is the log-value of transfers given/received, conditional on any transfer being given/received. ${ }^{\mathrm{xxx}}$ These models include the same covariates used in the logistic regression models above:

$$
\log \left(V_{h t} \mid P_{h t}=1\right)=\alpha+\beta Y_{h t}+\delta X_{h t}+\alpha_{t}+\alpha_{c}+\varepsilon_{h t}
$$


where $V_{h t}$ is the value of the transfer if any transfer occurred $\left(P_{h t}=1\right), \varepsilon_{h t}$ is an idiosyncratic normal error term with mean zero and variance $\sigma_{\varepsilon}^{2}$, and all other variables are defined as above. We also model the log-net value of transfers received using an OLS regression (including the same covariates as above), where the log-net value equals the log-value of transfers received minus the log-value of transfers given and the log-value of transfers received/given is set to zero if transfers received/given equal zero.

\section{Results: Transfer Models for all Household Types (Pooled)}

Table 4 presents regression estimates of the relationship between the five measures of household transfer activity and the control variables discussed above for all households pooled together regardless of their household type. Marginal effects, evaluated at the sample mean, are presented for the logistic regression models, while model coefficients are presented for the OLS

regressions. ${ }^{\text {xxvi }}$ All standard errors are estimated using the Huber/White method and allow for arbitrary correlation in a household's error term across years. Standard errors of the marginal effects are presented for the logistic regression models.

Household income acts in the predicted manner, having a strong positive association with the likelihood and value of transfers given, and a negative association with the likelihood and value of transfers received as well as net transfers received. Additional male adult household members are associated with a decreased likelihood and value of transfers given, and a decreased likelihood of transfers received (with no effect on the net outflow of transfers). Additional female adults are associated with no change in the likelihood of transfer received and an increase in the gross and net amount received. Additional children are associated with an increased likelihood and value of transfers received and an increased likelihood of transfers given, as well as a net inflow of transfers; these effects do not differ by the child's gender. 
The relationship between the number of elderly household members and transfers is more complex. An additional elderly male is associated with a higher likelihood and value of transfers given and a lower likelihood of receiving any transfer, but a higher value of transfers received. Taken together, the addition of an elderly male increases the net outflow of transfers from the household, but elderly males do appear to receive large transfers in some cases. Relative to the addition of an elderly male member, an additional elderly female is associated with a higher likelihood of receiving transfers and a net inflow of transfers (about a one-third reduction in the overall increase in the net outflow of transfers associated with an additional elder). Surprisingly, widowed households, compared to married households, are less likely to received transfers, receive less when they do get transfers, and have larger net outflows of transfers. In contrast, never married / divorced households have larger net inflows of transfers than married households.

The number of household members holding university degrees has a positive association with the likelihood and value of transfers given and a positive relationship with likelihood and value of transfers received, resulting in no change in net transfers received relative to the mean. Two possible hypotheses supported by this finding are: 1) university graduates participate in highly developed networks of concurrent financial exchange with one another; or 2) university graduates receive transfers during early life to subsidize job search and acquisition, but pay transfers out after acquiring such employment. Unexpectedly, the presence of children currently enrolled in school is associated with a lower likelihood and value of transfers received. The presence of individuals currently enrolled in university is positively associated with the likelihood and value of transfers received, and is strongly correlated with net transfer flows to households. 
Interpreting any of these results is difficult given the complex relationships between the covariates and transfer activity in the context of a pooled model. Using linear measures to accounti for the relationship between household structure and transfer activity may proxy for other variables that reflect Russia's complex demography (i.e. widows are typically women as are nearly all of the oldest elderly) or conceal important details (i.e. small households can consist entirely of young people just beginning their adult lives, empty-nesters, labor migrants, or elderly households). To address these concerns, we next estimate each model separately for the four single generation household types introduced in section IV: (1) Young Households; (2) Older Households with Children; (3) Older Households without Children; and (4) Elderly Households. Results: Models Stratified by Household Type (Young Households)

Table 5a presents estimates of the relationship between the five measures of household transfer activity and the control variables discussed above for young households. Income again has the predicted association with transfer behavior, positive for giving and negative for receiving and net received. Household structure effects for this group can be simplified to the inclusion of controls for total members, female adults, total children, and female children (leaving adult males as the reference category indicated by the main effect for total members and including a small number of elderly members in the appropriate adult categories).

Additional male adult members show only limited association with transfer behavior, resulting in decreased likelihood of giving or receiving any transfer, and no significant effect on net transfers received. Additional adult female members, however, are associated with increased likelihood and value of transfers received relative to additional male members, resulting in an overall positive association with net transfers received. Additional children are also associated with increased likelihood of receiving any transfer as well as an increase in net transfers 
received; these effects again do not differ by the child's gender.

The household's position in the life-course is further captured by controls for the average age of adults in the household, the age of the youngest child in the household, and whether the household is non-married (i.e. has no married members). These results depict the typical pattern of declining transfer receipts as household members age into adulthood; a one year increase in the average age of adults in the households is associated with a 1.3 percentage-point decline in likelihood of receiving a transfer, a 1.9 log-point (approx. 2\%) decrease in the value of transfers received, and a $5.2 \log$-point (approx. 5\%) decline in the net value of transfers received. Yet the results also indicate that the likelihood of receiving transfers is 10 percentage-points lower and the net value of transfers received is 33 log-points (approx. 40\%) lower for non-married households. While the general pattern suggests a shift towards net giving as households grow older, it also shows that marriage and childrearing can delay this shift.

Educational status also plays an important role in determining transfer activity. The addition of a household member who is attending university (about $6 \%$ of the households in this group have such a member) increases the likelihood of receiving transfers by 15 percentage-points, the value of transfer receipts by 28 log-points (approx. 30\%), and the net inflow of transfers by 64 log-points (approx. 90\%). Holding the other control variables constant, these are the largest effects any covariate in the model has on transfer activity for this household type. As in much of mainland Europe, where the state provides support for university students and young couples, interhousehold transfers appear to subsidize both adults living at home and attending university and young couples beginning to raise children.

Results: Models Stratified by Household Type (Older Households with Children)

Table $5 \mathrm{~b}$ presents results for older households with children. These models again show a strong 
income-transfer relationship. Few of the household composition variables are significant determinants of transfer activity besides the number of children in the household, which has a positive association with the likelihood of receiving transfers as well as with the net value of transfers received; again, these effects do not vary by the child's gender.

Measures of the household's position in the life-course are important determinants of transfer activity. Compared to married households, non-married households ( $16 \%$ of the households in this group) are less likely to give transfers and give less when they do give. This likely reflects the importance of precautionary savings (saving for a rainy day) for these predominately female headed households, as they are likely more vulnerable to future shocks from events such as job loss or health problems. The age of adults in the household is also an important determinant of transfer activity: a one year increase in their average age is associated with a 2.2 log-point (approx. $2 \%$ ) increase in the value of transfers given, a 0.7 percentage-point decrease in likelihood of receiving a transfer, and a 3.4 log-point (approx. 3\%) decline in the net value of transfers received. While these results hint at a gradual life-course transition towards making transfers to older parents and non-resident children, age effects for this group are smaller in magnitude than those found for either young households or older households without children, suggesting that childrearing obligations supersede parental support obligations.

Education effects add further weight to the role of child investments in both reducing transfers given and encouraging transfer receipt. Both the number of children in the household attending school and the number of older children and adults attending university is associated with an increase in net transfers received; a 10.5 log-point (approx. 11\%) increase per child attending school and a 22 log-point (approx. 25\%) increase per member attending university. For school children this overall effect is driven by a reduction in giving, while for university 
students it occurs because of an increase in receiving. The results for university attendance could reflect one of two processes: 1) the receipt of money for the education of extended family members temporarily residing in the household (for example, from rural areas); or 2) the receipt of support from non-household members, such as grandparents, for the education of household members. In either case, it is clear that investment in children's education is one of the primary uses of transfers.

Results: Models Stratified by Household Type (Older Households without Children)

Table $5 \mathrm{c}$ presents results for older households without children, a group largely consisting of "empty-nesters". Income effects for this group are large for the likelihood of giving transfers relative to the other household types (i.e. income has a greater association with the likelihood of giving transfers). Household composition is not strongly related to transfer activity for this household type. ${ }^{\text {xxxii }}$

Measures of the household's life-course position are again important determinants of transfer activity. Compared to married households, non-married households (32\% of the households in this group) are less likely to give transfers and give less when they do give, resulting in a $25-35 \%$ greater net inflow of transfers (not significant for widowed households). Again, this likely reflects the importance of precautionary savings for these households, but could also be a sign of a more limited network of social support partners. The age of the adults in the household is an important determinant of transfer activity: a one year increase in their average age is associated with a 0.9 percentage-point increase in the likelihood of giving a transfer, a 1.9 log-point (approx. 2\%) increase in the value of transfers given, a 0.5 percentagepoint decrease in likelihood of receiving a transfer, a 2.8 log-point (approx. 3\%) decrease in the value of transfers received, and a 4.9 log-point (approx. 5\%) decline in the net value of transfers 
received. The magnitude of this association is substantial: a household with an average adult age of 50 is estimated to have a $50 \%$ greater net outflow of transfers than a households with an average age of 40 . Households in this group continue to support their non-resident children, while apparently drawing little support in return.

Educational effects have only a limited impact on transfer behavior for this group, as much of the effect of education is probably captured though the effect of education on household income. Additional university and professional school graduates in the household are associated with an increased likelihood of giving transfers, but have no effect on any other transfer activity or net transfer flows. This positive association between making transfers and education may reflect the greater likelihood that a university educated respondent has children currently attending university and not living at home.

\section{Results: Models Stratified by Household Type (Elderly Households)}

Table $5 \mathrm{~d}$ presents results for elderly households. Income again has the expected association with transfer activity; net transfer flows are more strongly associated with income for these households than for other household types. As only $11 \%$ of elderly households have children living in the household, we capture the effect of children on transfer activity with a dichotomous variable indicating the presence of children in the household. Having children in the household is associated with a greater net inflow of transfers, as we found for both young households and older households with children. As most married elderly households have only two members (not including children) and most non-married elderly households have only one member, simplified household composition variables control for the number of additional (female) adult and elderly in each household beyond these norms. Additional adult or elderly members in the households are negatively associated with the likelihood of giving transfers and positively 
associated with the net value of transfers received; these effects do not depend on gender.

Measures of the household's position in the life-course are also important determinants of transfer activity. The results for these variables highlight the role of transfers in supporting vulnerable groups of the population in spite of the overall outflow of transfers from elderly households. Compared to married households, widowed and divorced / never married households (which together comprise 54\% of the households in this group) are again less likely to give transfers and give less when they do give. When they receive transfers, these transfers are also likely to be of lower value, yet on the whole they still receive a $10-20 \%$ greater net inflow of transfers than do married households (effects are significant for widowed, but not for divorced / never married households). The tendency towards declining transfer activity may again reflect the importance of precautionary savings for these households or could be a sign of a more limited network of social support partners.

The age of the oldest elderly household member is also correlated with transfer activity: a one year increase in their age is associated with a 0.1 percentage-point decrease in the likelihood of giving a transfer and a $0.4 \log$-point (approx. $0.5 \%$ ) increase in the net value of transfers received. As a consequence of Russia's unique demographic structure, the oldest elderly household member is usually a women (true in around $70 \%$ of all households). The oldest old, of either gender, also have less ability to supplement their pension income, and likely have higher health and personal care expenditures. The decreasing outflow of transfers associated with the aging of these members is consistent with the need to cope with these changes over the life course.

Results: Long-Term Differences versus Short-Run Fluctuations in Resources

Previous regression models use log household income as our measure of household resources. In 
this section, we attempt to separate the effect of long-run household resources from the effect of short-run resource fluctuations. As our measure of long run resources, we include the average of log household income across the five survey waves, referred to as "permanent household income." Fluctuations in resources, referred to as "transitory household income," are captured by the difference between log household income in a survey year and the long-run average.

Table 6 summarizes the effects of household resources on transfer activity for each of the groups analyzed in tables 4 and 5 . Although not shown in the table, the effect of other covariates on transfer activity are quite similar to those presented above. In the first section of each panel, we reproduce the appropriate results from the regressions where household resources are measured by only log household income. In the second section of each panel, we present results where the effect of household resources on transfer activity is separated into short-run and longrun components.

In separate specifications used only for elderly households, household resources are instead measured as permanent and transitory log household pension income. As shown in table 1, three-fourths of elderly household income comes from pensions. Retirement pension values in Russia depend solely on an individual's wage in the years prior to the official retirement age (55 for women, 60 for men) and are not reduced if he/she remains employed after this cutoff. The two sources of variation in elderly pension income are: (1) inflation (nominal pensions are partially indexed for inflation, but are typically slow to adjust to changes in the price level; and (2) pension arrears (a fairly common occurrence during the transition period). Thus, variation in real pension income over time is exogenous to elderly households (with the caveat that this variation could affect household composition) and can be used to identify the causal effect of changes in household resources on transfer activity. 
In all cases, short-run changes and long-run differences in household resources affect transfer activity in the same direction. But the relative importance of the income components is not consistent across groups. Income, and particularly transitory changes in income, has a stronger association with the likelihood and value of transfers given by older households without children and elderly households compared to other households. This is consistent with the flexible life-course role played by these households for whom children have left the home. Older households without children are also the only group for whom either low permanent income or negative shocks to income do not predict increased value of transfers received, although likelihood of receiving transfers does increase.

A life-course transfer model can also account for some of the differences in the income/transfer relationship for younger households and older households with children. Transitory changes in household resources have almost no effect on the likelihood and value of transfers given by younger households and a small effect for older households with children. This reflects the primacy of concerns over the security of nuclear family members, and the priority placed on asset accumulation during the childrearing and career-building stages of the life-course. Yet it is interesting to note that the likelihood of receiving transfers and the value of transfers received by young households is positively related both to low permanent income and to negative transitory shocks to income. Young households retain their surplus income, yet they readily receive further support in cases of deficit.

Income effects also do much to explain the tendency for elderly households to be net givers of transfers. For elderly households, the income effects are dominated by the tendency to give large transfers if permanent income is high. Yet they also reflect a tendency towards high likelihood and value of transfers received when transitory income is low. Taken together, the 
results suggest that wealthy elderly households make regular transfers to their children, yet do receive some return transfers if they face a particularly bad year.

Looking at the effect of pension income allows us to isolate the response of transfers to exogenous variation in elderly household resources. Both permanent and transitory pension income has little effect on elderly transfer receipt. This suggests that the overall negative effect of income on transfer receipt, found above, is picking up an endogenous response of elderly households to changes in transfers receipt (e.g. households work less if they expect to receive transfers). Both permanent and transitory pension income are positively associated with the likelihood of giving transfers; a 10 log-point (approx. 10\%) change in a household's long-term pension value leads to a 1 percentage-point (approx. $4 \%=.01 / .25$ ) change in the marginal likelihood of making a transfer, while short-run fluctuations in pension value have around forty percent of the impact of long-run differences. Transfer value is also positively associated with both permanent and transitory pension income; a 10 log-point (approx. 10\%) change in longterm pension income leads to a 2.2 log-point (approx $2 \%$ ) change in transfer value if a transfer is made; short-run fluctuations in pension value have a similar size effect on transfer values. Taken together, the results suggest that elderly households consistently distribute pension income to their children, and give more (less) when pension values are higher (lower) than usual.

\section{VI) Conclusion and Discussion}

The transfer patterns depicted in this paper appear to deviate from most empirical observations of life-course transfer behavior both in developed and developing countries, while offering no suggestions of an anticipated crisis of support among Russia's elderly. At the macro-level, net transfers in Russia largely flow from elderly and "empty-nest" households to younger households. While these transfers perform the empirically recognized role of subsidizing young adults as they transition to the job market, they also grow larger after marriage and larger still 
with the addition of children to the household. Yet the results also suggest a micro-level tendency for transfers to flow to the most vulnerable elderly respondents, including those facing negative economic shocks, the oldest old, and widows.

The tendency for households in their prime earning years to depend on transfers from the older generation is more likely to be an artifact of Russia's current cycle of economic transition than to suggest any unique failure of Russian intergenerational transfer mechanisms. As in developing countries with limited public transfer systems, Russia's familial transfer system continues to reproduce the public goal of income redistribution within the private context of the family. In the current context, transfers allow older Russians to subsidize working-age families who are adjusting to a newly developed non-Soviet labor market. Transfer patterns among elderly pensioners further suggest that secure forms of public transfer income are readily transferred through private channels. After 75 years under the all-encompassing Soviet public transfer system, private transfers continue to play a crucial role in redistributing income over the life course, and between rich and poor households.

While Russia bears similarity to Japan, Germany, and other European nations in terms of an aging labor force, rising old-age dependency, and strong elderly political advocacy, inter-familial transfers appear to mitigate any burdens that population aging might place on younger generations. In the process, transfers may play a vital role in Russia's economic re-birth: while other aging societies have suffered declining investments in children as the public burden of oldage support has grown, the current results suggest that older Russians play a significant role in supporting the younger ones, particular during an era of economic and demographic upheaval. 
i Gary S. Becker, “A Theory of Social Interactions,” Journal of Political Economy 82 (November/December 1974): 1063-94.

ii Oded Stark, Altruism and Beyond: An Economic Analysis of Transfers and Exchanges in Families and Groups (Cambridge: Cambridge University Press, 1995); Robert Willis, "The Direction of Intergenerational Transfers and Demographic Transition," Population and Development Review 8 (1982 Supplement): 207-23.

iii Laurence J. Kotlikoff and Lawrence H. Summers, “The Role of Intergenerational Transfers in Aggregate Capital Accumulation,” Journal of Political Economy 89 (1981): 706-32; Robert E.B. Lucas and Oded Stark, "Motivations to Remit: Evidence from Botswana," Journal of Political Economy 93 (October 1985): 1-18.

${ }^{\text {iv }}$ Ethan Ligon, Jonathan P. Thomas and Tim Worrall, “Informal Insurance Arrangements with Limited Commitment: Theory and Evidence from Village Economies," Review of Economic Studies 69 (2002): 209-244; Mark R. Rosenzweig and Oded Stark, "Consumption Smoothing, Migration, and Marriage," Journal of Political Economy 97 (August, 1989): 905-26.

${ }^{\mathrm{vv}}$ Willis, "Intergenerational Transfers," 1982; John C. Caldwell, "Toward a Restatement of Demographic Transition Theory," Population and Development Review 2 (1976): 321-66.

${ }^{\text {vi }}$ Lee A. Lillard and Robert J. Willis, "Motives for Intergenerational Transfers: Evidence from Malaysia," Demography 34 (February 1997): 115-34.

${ }^{\text {vii }}$ Mark R. Rosenzweig, "Population Growth and Human Capital Investments: Theory and Evidence," Journal of Political Economy 98 (1990): S38-S70.

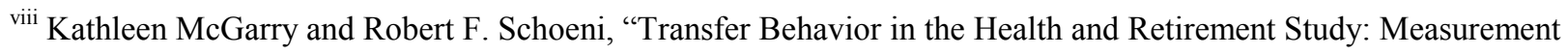
and the Redistribution of Resources within the Family," Journal of Human Resources 30 (1995): S184-S226.

${ }^{\text {ix }}$ Caldwell, "Demographic Transition Theory", 1976.

${ }^{x}$ Ronald Lee, “A Cross Cultural Perspective on Intergenerational Transfers and the Economic Life Cycle,” in Andrew Mason and Georges Tapinos, eds., Sharing the Wealth: Demographic Change and Economic Transfers between Generations (Oxford: Oxford University Press, 2000).

${ }^{x i}$ Samuel H. Preston, “Children and the Elderly: Divergent Paths for America's Dependents,” Demography 21 (1984): 435-57. 
xii John Knodel, Napaporn Chayovan, and Siriwan Siriboon, “The Impact of Fertility Decline on Familial Support for The Elderly," Population and Development Review 18 (1992): 79-103.

xiii Robert Townsend, “Risk and Insurance in Village India,” Econometrica 62 (May 1994): 539-91.

${ }^{\text {xiv }}$ Rosenzweig and Stark, “Consumption Smoothing”, 1989.

${ }^{x v}$ Abhijit Banerjee and Kaivan Munshi, "Networks, Migration and Investment: Insiders and Outsiders in Tirupur's Production Cluster,” MIT Department of Economics Working Paper Series, 2000.

xvi Donald Cox, “Motives for Private Income Transfers," Journal of Political Economy 93 (June 1987): 1045-76.

xvii Donald Cox and Emmanuel Jimenez, "Private Transfers and Public Policy in Developing Countries: A Case Study for Peru," World Bank Economic Review 6 (1992): 155-69.

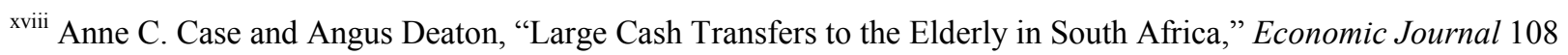
(1998): 1330-61.

${ }^{\text {xix }}$ Quarterly data on nominal GDP are obtained from IMF International Financial Statistics Online (imf.largo.apdi.net). Biweekly data on the official nominal dollar-ruble exchange rate are obtained from the Central Bank of Russia (www.cbr.ru/eng/currency_base/dynamics.asp). Each series is appropriately deflated using monthly CPI data available from Goskomstat (The Russian Federation Statistical Agency - www.gks.ru/eng/) and the US Bureau of Labor Statistics (http://www.bls.gov/cpihome.htm), and is averaged over the appropriate time period. Russia's real GDP is seasonally adjusted by regressing the series on quarterly indicator variables.

${ }^{\mathrm{xx}}$ The magnitude of this decline is similar to that experienced in the US during the first year of the Great Depression and in Indonesia during their economic crisis in early 1998. As shown in Steven Stillman, "The Response of Consumption in Russian Households to Economic Shocks," IZA Discussion Paper 411 (December 2001), the crisis had strong direct effects on Russian households with both household income and non-durable expenditure declining by $25-30 \%$ between the fall of 1996 and the fall of 1998 .

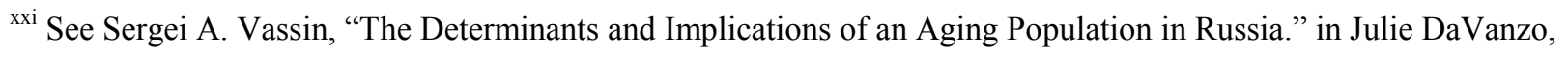
ed., "Russia's Demographic Crisis" (Santa Monica, CA: RAND CF-124, 1996) for a thorough discussion.

xxii Robert T Jenson and Kaspar Richter, "The Health Implications of Social Security Failure: Evidence from the Russian Financial Crisis," draft, 2002 describe the Russian pension system in greater detail. Russia's decentralized 
system of pension collection and payment has led to large spatial variation in the occurrence of arrears. Individual characteristics appear to have little effect on the likelihood of an individual receiving their pension on time.

xxiii Donald Cox, Zekeriya Eser, and Emmanuel Jimenez, "Family Safety Nets During Economic Transition: A Study of Inter-Household Transfers in Russia," in Jeni Klugman, ed., Poverty in Russia: Public Policy and Private Response (Washington, DC: The World Bank, 1997). A few papers examine interhousehold transfers in other transition economies, including Donald Cox, James Fetzer and Emmanuel Jimenez, "Private Transfers in Vietnam," in David Dollar, Paul Glewwe and Jennie Litvack, eds., Household Welfare and Vietnam's Transition to a Market Economy (Washington, DC: The World Bank, forthcoming); and Donald Cox, Emmanuel Jimenez and Wlodek Okrasa, "Family Safety Nets and Economic Transition: A Study of Worker Households in Poland," Review of Income and Wealth 43 (June 1997): 191-209.

${ }^{\text {xxiv }}$ Surveys in phase II were conducted in the late fall of 1994, 1995, 1996, 1998, and 2000 (rounds 5 through 9 , respectively): in November and December, 1994; October and November, 1995; October and November, 1996; November and December, 1998; and October and November, 2000. A full project description, which includes sampling procedures, survey instruments, and field protocols, is available at www.cpc.unc.edu/rlms.

${ }^{\mathrm{xxv}}$ See Duncan Thomas, Elizabeth Frankenberg and James P. Smith, “Lost but Not Forgotten: Attrition and FollowUp in the Indonesia Family Life Survey," Journal of Human Resources 36 (Summer 2001): 556-92 for a discussion of the likely implications of this assumption.

${ }^{\text {xxvi }}$ All individuals in each household are surveyed with the exception of some elderly and very young members. Extensive data are collected for each of the 159 survey sites. Information is provided to assign the 159 sites to 38 raion (county) level primary sampling units (PSUs) and to 12 regions.

xxvii $8 \%$ of the households were interviewed in one wave, $9 \%$ in two waves, $9 \%$ in three waves, $15 \%$ in four waves, and $59 \%$ were interviewed in all five waves of phase II.

xxviii Total household income is asked of the household respondent, typically the senior woman in the household. All values are for the month prior to the interview. Nominal values are deflated using a chain-weighted communitylevel Tornqvist price index (1998 Moscow City is the base community-year) which is calculated using household expenditure and community price data from RLMS. As discussed in Angus Deaton, John Muellbauer, Economics 
and Consumer Behavior (Cambridge: Cambridge University Press, 1980), at a second-order approximation this is the true index for any arbitrary cost function.

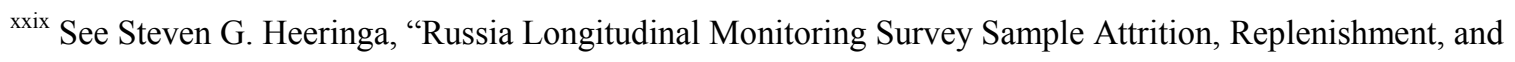
Weighting: Rounds V-VII,” University of Michigan Institute for Social Research (March 1997) for more information on attrition in RLMS and further discussion of its overall representativeness.

${ }^{\mathrm{xxx}}$ Households in the same raion (county) and with the same urban status are aggregated together to form communities. There are 20 rural and 33 urban communities in RLMS representing 32 out of 89 oblasts (states) in Russia. The average community has 75 surveyed households per year with the smallest having 10 and the largest 264.

${ }^{\text {xxi }}$ All questions on interhousehold transfer activity are only collected from the household respondent, typically the senior woman in the household. Thus the different possible transfer targets are based on their relationship to this respondent alone. For example, transfers from the parents-in-law of an adult household respondent would be listed in the other category, not in the parent category. Separate questions are asked about transfers to/from the three groups listed above as well as to/from grandchildren and grandparents which we aggregated into the other category. xxxii The official retirement age in Russia for women is 55 and for men 60. At this point individuals become eligible for retirement pensions, which are not means-tested. As this is an important life-course transition, we use these cutoffs for our age categories.

${ }^{\text {xxxiii }}$ Households with at least one married member are married households, those with at least one widowed member and no married members are widowed households, and those with neither married nor widowed members are never married/divorced households. Married households are the default group in our regression analysis.

${ }^{\text {xxxiv }}$ This is the standard normalization of the error variance used when estimating logistic regression models. We are able to produce consistent estimates of both the year and community fixed effects because, in each case, group size tends towards infinity when the number of years or communities is held constant.

${ }^{\mathrm{xxxv}}$ We chose to model transfer values and household income using log-values because of the skewness in the distribution of household income, transfers received, and transfers given. We explored modeling these relationships linearly, but achieved much better model fit using the double-log specification. We also explored using either a 
tobit or heckman regression model to estimate the determinants of unconditional transfer values, but decided that the restrictions necessary for estimation were unrealistic (a tobit model assumes that all model covariates effect the likelihood of giving/receiving and the amount given/received in a similar manner (the same proportional relationship for all covariates), while a heckman model requires that at least one covariate exists which effects the likelihood of giving/receiving transfers but does not effect the amount given/received).

${ }^{\text {xxxvi }}$ For discrete variables in the logistic model, marginal effects are calculated as the change in the independent variable which occurs when the variable is switched from zero to one.

xxxvii This is partially due to the fact that household composition varies little across households in this group. By definition, households have no children and a limited number of elderly (only possible if the household respondent is married to an elderly member). Thus, we group elderly and adult members in this specification, and the only variation occurs because households have a different number of male and female members.

${ }^{\text {xxxviii }}$ Robert T Jenson and Kaspar Richter, "The Health Implications of Social Security Failure: Evidence from the Russian Financial Crisis,” draft, 2002 describe the Russian pension system in greater detail. Russia’s decentralized system of pension collection and payment has led to large spatial variation in the occurrence of arrears. Individual characteristics appear to have little effect on the likelihood of an individual receiving their pension on time. 
Seasonally Adjusted RGDP

Consumer Price Index

- - - - \$ / Ruble Exchange Rate

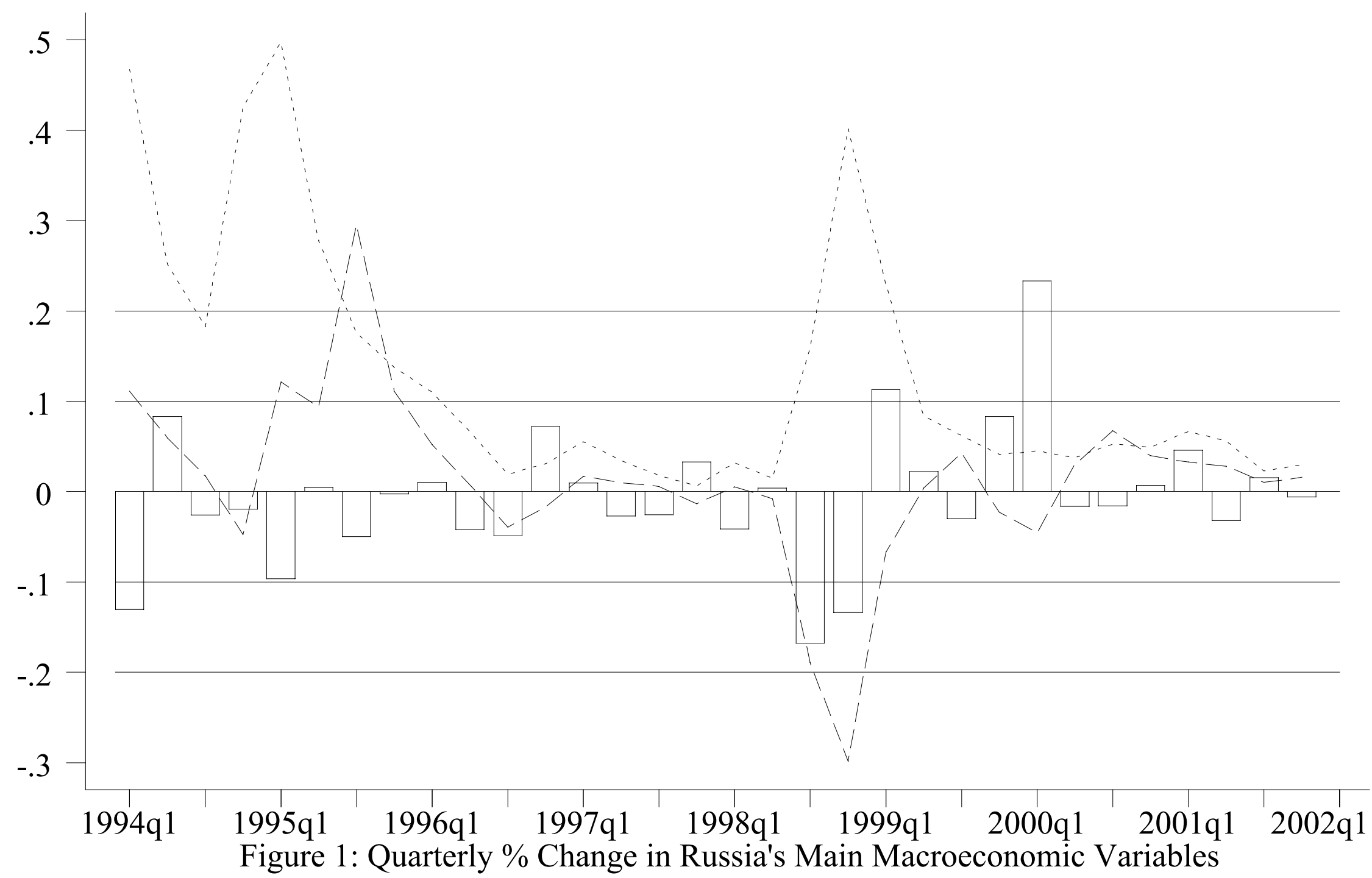




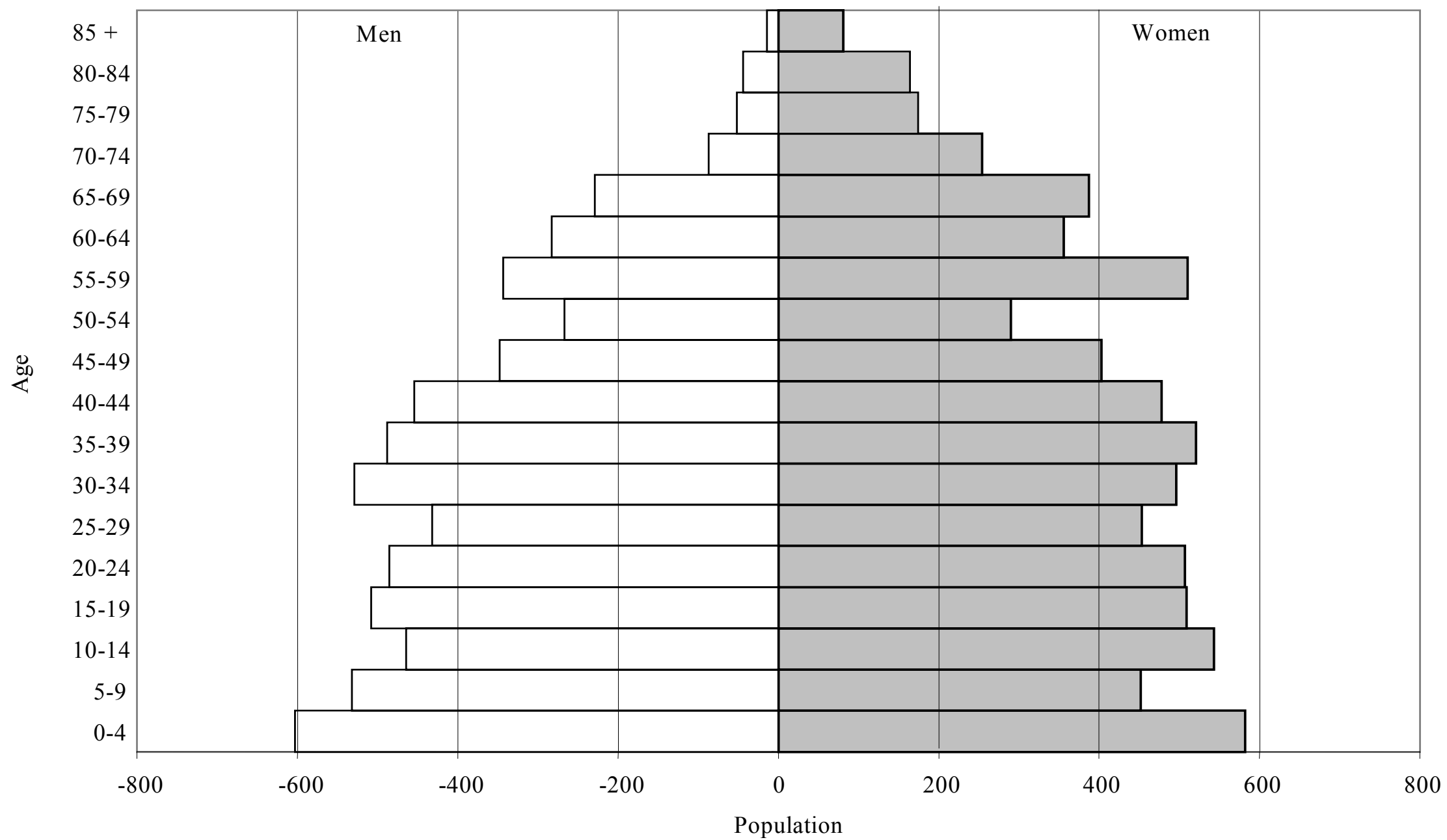

Figure 2: RLMS Round 5 Population Pyramid 
Table 1: Summary Statistics

\begin{tabular}{|c|c|c|c|c|}
\hline Mean (Standard Deviation) & Full Sample & Round 5 & Rural & Urban \\
\hline \multirow[t]{2}{*}{ Total Household Income } & 2180 & 2534 & 1452 & 2433 \\
\hline & $(3184)$ & $(3627)$ & $(2476)$ & $(3359)$ \\
\hline \multirow[t]{2}{*}{ Household Income (Elderly Households) } & 1193 & 1431 & 924 & 1315 \\
\hline & $(1521)$ & $(1414)$ & $(1110)$ & $(1660)$ \\
\hline \multirow[t]{2}{*}{ Pension Income (Elderly Households) } & 815 & 981 & 715 & 860 \\
\hline & $(559)$ & $(605)$ & $(544)$ & $(559)$ \\
\hline Received Transfers & $23 \%$ & $22 \%$ & $18 \%$ & $25 \%$ \\
\hline \multirow{2}{*}{ Amount Received } & 200 & 227 & 149 & 217 \\
\hline & $(831)$ & (891) & $(775)$ & (849) \\
\hline Gave Transfers & $24 \%$ & $29 \%$ & $22 \%$ & $24 \%$ \\
\hline \multirow[t]{2}{*}{ Amount Given } & 135 & 161 & 134 & 135 \\
\hline & $(548)$ & $(568)$ & $(596)$ & $(530)$ \\
\hline \multirow[t]{2}{*}{ Net Transfers Received } & 65 & 69 & 15 & 83 \\
\hline & $(981)$ & $(1042)$ & $(961)$ & $(988)$ \\
\hline \multirow[t]{2}{*}{ Number of Household Members } & 3.10 & 3.35 & 3.30 & 3.03 \\
\hline & $(1.62)$ & $(1.76)$ & $(1.91)$ & $(1.50)$ \\
\hline \multirow[t]{2}{*}{ Number of Children $($ age $<20)$} & 0.91 & 1.05 & 1.07 & 0.86 \\
\hline & $(1.07)$ & $(1.18)$ & $(1.33)$ & $(0.96)$ \\
\hline \multirow[t]{2}{*}{ Number of Elderly (age $>59(\mathrm{M})$ or $54(\mathrm{~F})$ ) } & 0.65 & 0.67 & 0.78 & 0.60 \\
\hline & $(0.78)$ & $(0.79)$ & $(0.81)$ & $(0.76)$ \\
\hline \multirow[t]{2}{*}{ Number of Married Household Members } & 1.53 & 1.59 & 1.57 & 1.51 \\
\hline & $(1.12)$ & $(1.15)$ & $(1.14)$ & $(1.12)$ \\
\hline \multirow[t]{2}{*}{ Number Currently Enrolled in Grade School } & 0.45 & 0.44 & 0.52 & 0.42 \\
\hline & $(0.74)$ & $(0.74)$ & $(0.87)$ & $(0.68)$ \\
\hline \multirow[t]{2}{*}{ Number Currently Enrolled in University } & 0.08 & 0.08 & 0.04 & 0.10 \\
\hline & $(0.30)$ & $(0.29)$ & $(0.21)$ & $(0.32)$ \\
\hline \multirow[t]{2}{*}{ Number Completed General Secondary Educ. } & 1.30 & 1.31 & 1.14 & 1.35 \\
\hline & $(1.09)$ & $(1.12)$ & $(1.15)$ & $(1.07)$ \\
\hline \multirow[t]{2}{*}{ Number with University Diploma } & 0.38 & 0.40 & 0.17 & 0.45 \\
\hline & $(0.69)$ & $(0.72)$ & $(0.47)$ & $(0.74)$ \\
\hline \multirow[t]{2}{*}{ Number with Professional Course Diploma } & 0.63 & 0.61 & 0.67 & 0.61 \\
\hline & $(0.78)$ & $(0.77)$ & $(0.77)$ & $(0.78)$ \\
\hline Year is 1994 & $21 \%$ & $100 \%$ & $20 \%$ & $21 \%$ \\
\hline Year is 1995 & $20 \%$ & $0 \%$ & $19 \%$ & $20 \%$ \\
\hline Year is 1996 & $19 \%$ & $0 \%$ & $20 \%$ & $19 \%$ \\
\hline Year is 1998 & $20 \%$ & $0 \%$ & $20 \%$ & $20 \%$ \\
\hline Year is 2000 & $21 \%$ & $0 \%$ & $22 \%$ & $20 \%$ \\
\hline Urban Household & $74 \%$ & $75 \%$ & & \\
\hline Region is Moscow City & $5 \%$ & $7 \%$ & $0 \%$ & $7 \%$ \\
\hline Region is Northwest (includes St. Petersburg) & $5 \%$ & $6 \%$ & $7 \%$ & $5 \%$ \\
\hline Region is North & $5 \%$ & $5 \%$ & $2 \%$ & $6 \%$ \\
\hline Region is Central & $15 \%$ & $15 \%$ & $16 \%$ & $15 \%$ \\
\hline Region is Central Black-Earth & $5 \%$ & $5 \%$ & $2 \%$ & $6 \%$ \\
\hline Region is Volga-Vaytski & $5 \%$ & $5 \%$ & $4 \%$ & $6 \%$ \\
\hline Region is Volga & $13 \%$ & $12 \%$ & $13 \%$ & $13 \%$ \\
\hline Region is North Caucasia & $12 \%$ & $12 \%$ & $22 \%$ & $9 \%$ \\
\hline Region is Ural & $15 \%$ & $14 \%$ & $11 \%$ & $16 \%$ \\
\hline Region is West Siberia & $10 \%$ & $10 \%$ & $11 \%$ & $9 \%$ \\
\hline Region is East Siberia & $5 \%$ & $5 \%$ & $3 \%$ & $6 \%$ \\
\hline Region is Far East & $5 \%$ & $5 \%$ & $10 \%$ & $3 \%$ \\
\hline \# Households & 19113 & 3935 & 4931 & 14182 \\
\hline
\end{tabular}

Note: All values are in real 1998 Moscow City rubles ( 1 USD $\cong 17$ real rubles) and are for the month previous the survey. 
Table 2: The Distribution of Household Income and Transfers

\begin{tabular}{|c|c|c|c|c|c|c|c|c|}
\hline & Mean & $\begin{array}{c}\text { Standard } \\
\text { Deviation }\end{array}$ & $10^{\text {th }}$ Percentile & $\begin{array}{c}25 \text { th } \\
\text { Percentile }\end{array}$ & Median & $\begin{array}{c}75 \text { th } \\
\text { Percentile }\end{array}$ & $\begin{array}{c}\text { 90th } \\
\text { Percentile }\end{array}$ & \# Households \\
\hline \multicolumn{9}{|c|}{ Rural Households } \\
\hline Total Household Income & 1452 & 2476 & 0 & 408 & 914 & 1723 & 3125 & 4931 \\
\hline Pension Income (Elderly Households) & 715 & 544 & 0 & 396 & 609 & 1065 & 1427 & 1776 \\
\hline Amount of Transfers Received & 149 & 775 & 0 & 0 & 0 & 0 & 289 & 4921 \\
\hline Amount of Transfers Given & 134 & 596 & 0 & 0 & 0 & 0 & 333 & 4909 \\
\hline Net Transfers Received & 15 & 961 & -277 & 0 & 0 & 0 & 218 & 4931 \\
\hline Net Transfers / After Transfer Income & 0.09 & 0.24 & 0.00 & 0.00 & 0.00 & 0.00 & 0.35 & 3520 \\
\hline Household Income if Net Transfers $<0$ & 2029 & 3308 & 290 & 665 & 1265 & 2213 & 3717 & 913 \\
\hline Household Income if Net Transfers $>0$ & 1030 & 2464 & -228 & 63 & 579 & 1328 & 2912 & 771 \\
\hline \multicolumn{9}{|c|}{ Urban Households } \\
\hline Total Household Income & 2433 & 3359 & 356 & 769 & 1600 & 3028 & 5106 & 14182 \\
\hline Pension Income (Elderly Households) & 860 & 559 & 331 & 520 & 729 & 1171 & 1583 & 3917 \\
\hline Amount of Transfers Received & 217 & 849 & 0 & 0 & 0 & 0 & 550 & 14145 \\
\hline Amount of Transfers Given & 135 & 530 & 0 & 0 & 0 & 0 & 356 & 14113 \\
\hline Net Transfers Received & 83 & 988 & -277 & 0 & 0 & 0 & 487 & 14182 \\
\hline Net Transfers / After Transfer Income & 0.09 & 0.21 & 0.00 & 0.00 & 0.00 & 0.03 & 0.36 & 10797 \\
\hline Household Income if Net Transfers $<0$ & 3369 & 4200 & 682 & 1256 & 2198 & 3956 & 6612 & 2783 \\
\hline Household Income if Net Transfers $>0$ & 1665 & 2973 & 0 & 436 & 1056 & 2200 & 3934 & 3149 \\
\hline
\end{tabular}

Note: All values are in real 1998 Moscow City rubles ( 1 USD $\cong 17$ real rubles) and are for the month previous the survey. 
Table 3: Detailed Interhousehold Transfers by Source and Household Structure

\begin{tabular}{|c|c|c|c|c|c|c|c|}
\hline \multirow{2}{*}{$\begin{array}{l}\text { Type of Household } \\
\text { Household Respondent's Age }\end{array}$} & \multicolumn{4}{|c|}{ Single Generation } & \multicolumn{3}{|c|}{ Multi-Generation } \\
\hline & $<35$ & $\begin{array}{l}34-54 \\
\text { w/ Kids }\end{array}$ & $\begin{array}{c}34-54 \\
\text { w/o Kids }\end{array}$ & $>54$ & $<35$ & $34-54$ & $>54$ \\
\hline \multicolumn{8}{|c|}{ Rural Households } \\
\hline (i) Received Transfers & $37 \%$ & $18 \%$ & $14 \%$ & $13 \%$ & $25 \%$ & $12 \%$ & $10 \%$ \\
\hline Total Received if Any & 831 & 955 & 511 & 725 & 1279 & 1151 & 630 \\
\hline a) Received from Parents & $33 \%$ & $11 \%$ & $7 \%$ & $0 \%$ & $16 \%$ & $5 \%$ & $2 \%$ \\
\hline Amount Received if Any & 736 & 804 & 422 & 1542 & 895 & 862 & 596 \\
\hline b) Received from Children & $1 \%$ & $2 \%$ & $4 \%$ & $10 \%$ & $1 \%$ & $1 \%$ & $6 \%$ \\
\hline Amount Received if Any & 696 & 562 & 384 & 569 & 88 & 120 & 404 \\
\hline c) Received from Others & $12 \%$ & $8 \%$ & $5 \%$ & $5 \%$ & $15 \%$ & $7 \%$ & $5 \%$ \\
\hline Amount Received if Any & 352 & 685 & 603 & 510 & 984 & 1102 & 655 \\
\hline (ii) Gave Transfers & $13 \%$ & $18 \%$ & $24 \%$ & $26 \%$ & $17 \%$ & $25 \%$ & $22 \%$ \\
\hline Total Given if Any & 340 & 564 & 1081 & 589 & 776 & 889 & 491 \\
\hline a) Gave to Parents & $7 \%$ & $6 \%$ & $3 \%$ & $1 \%$ & $3 \%$ & $2 \%$ & $1 \%$ \\
\hline Amount Given if Any & 273 & 410 & 600 & 239 & 497 & 705 & 158 \\
\hline b) Gave to Children & $0 \%$ & $8 \%$ & $19 \%$ & $19 \%$ & $4 \%$ & $15 \%$ & $14 \%$ \\
\hline Amount Given if Any & 88 & 719 & 977 & 600 & 267 & 773 & 461 \\
\hline c) Gave to Others & $8 \%$ & $8 \%$ & $9 \%$ & $11 \%$ & $13 \%$ & $12 \%$ & $11 \%$ \\
\hline Amount Given if Any & 281 & 266 & 236 & 305 & 470 & 427 & 338 \\
\hline (iii) Net Transfers Received & 257 & 66 & -190 & -58 & 190 & -83 & -42 \\
\hline a) Net Received from Parents & 217 & 61 & 11 & 5 & 124 & 28 & 9 \\
\hline b) Net Received from Children & 3 & -46 & -161 & -59 & -9 & -116 & -41 \\
\hline c) Net Received from Others & 19 & 34 & 9 & -10 & 85 & 23 & -3 \\
\hline \# Households & 768 & 1083 & 370 & 1790 & 143 & 323 & 454 \\
\hline \multicolumn{8}{|c|}{ Urban Households } \\
\hline (i) Received Transfers & $44 \%$ & $23 \%$ & $19 \%$ & $19 \%$ & $25 \%$ & $19 \%$ & $13 \%$ \\
\hline Total Received if Any & 1094 & 933 & 805 & 472 & 1044 & 921 & 672 \\
\hline a) Received from Parents & $40 \%$ & $16 \%$ & $8 \%$ & $0 \%$ & $15 \%$ & $9 \%$ & $2 \%$ \\
\hline Amount Received if Any & 927 & 746 & 675 & 1010 & 719 & 622 & 1091 \\
\hline b) Received from Children & $0 \%$ & $1 \%$ & $4 \%$ & $11 \%$ & $0 \%$ & $1 \%$ & $4 \%$ \\
\hline Amount Received if Any & 648 & 495 & 526 & 455 & NA & 386 & 630 \\
\hline c) Received from Others & $16 \%$ & $10 \%$ & $11 \%$ & $9 \%$ & $14 \%$ & $10 \%$ & $8 \%$ \\
\hline Amount Received if Any & 685 & 864 & 674 & 308 & 1007 & 1033 & 455 \\
\hline (ii) Gave Transfers & $22 \%$ & $25 \%$ & $33 \%$ & $24 \%$ & $19 \%$ & $22 \%$ & $21 \%$ \\
\hline Total Given if Any & 488 & 552 & 678 & 520 & 488 & 565 & 607 \\
\hline a) Gave to Parents & $12 \%$ & $10 \%$ & $8 \%$ & $1 \%$ & $4 \%$ & $6 \%$ & $2 \%$ \\
\hline Amount Given if Any & 478 & 432 & 361 & 215 & 405 & 463 & 312 \\
\hline b) Gave to Children & $1 \%$ & $7 \%$ & $19 \%$ & $15 \%$ & $2 \%$ & $8 \%$ & $11 \%$ \\
\hline Amount Given if Any & 506 & 722 & 719 & 531 & 312 & 616 & 588 \\
\hline c) Gave to Others & $13 \%$ & $14 \%$ & $17 \%$ & $15 \%$ & $15 \%$ & $14 \%$ & $12 \%$ \\
\hline Amount Given if Any & 281 & 289 & 307 & 269 & 417 & 278 & 376 \\
\hline (iii) Net Transfers Received & 382 & 75 & -72 & -38 & 165 & 49 & -40 \\
\hline a) Net Received from Parents & 303 & 74 & 23 & 2 & 85 & 32 & 19 \\
\hline b) Net Received from Children & -5 & -44 & -116 & -27 & -5 & -41 & -41 \\
\hline c) Net Received from Others & 73 & 45 & 22 & -10 & 80 & 67 & -9 \\
\hline \# Households & 2938 & 3484 & 1579 & 3936 & 377 & 742 & 1126 \\
\hline
\end{tabular}

Note: All values are in real 1998 Moscow City rubles (1 USD $\cong 17$ real rubles) and are for the month previous the survey. 
Table 4: Estimated Covariates of Household Transfer Activity (All Households Pooled)

\begin{tabular}{|c|c|c|c|c|c|}
\hline Dependent Variable & $\begin{array}{c}(1) \\
\text { Gave } \\
\text { Transfers }\end{array}$ & $\begin{array}{c}\text { (2) } \\
\text { Log Amount } \\
\text { Given if Any }\end{array}$ & $\begin{array}{c}\text { (3) } \\
\text { Received } \\
\text { Transfers }\end{array}$ & $\begin{array}{c}\text { (4) } \\
\text { Log Amount } \\
\text { Received if Any }\end{array}$ & $\begin{array}{c}(5) \\
\text { Log Net } \\
\text { Transfers } \\
\text { Received }\end{array}$ \\
\hline Log Household Income & $\begin{array}{c}0.061 * * * \\
(0.004)\end{array}$ & $\begin{array}{c}0.216^{* * * *} \\
(0.021)\end{array}$ & $\begin{array}{c}-0.066^{* * *} \\
(0.003)\end{array}$ & $\begin{array}{c}-0.174 * * * \\
(0.018)\end{array}$ & $\begin{array}{c}-0.503 * * * \\
(0.017)\end{array}$ \\
\hline Number of Household Members & $\begin{array}{c}-0.065 * * * \\
(0.009)\end{array}$ & $\begin{array}{c}-0.108 * * \\
(0.046)\end{array}$ & $\begin{array}{c}-0.042 * * * \\
(0.008)\end{array}$ & $\begin{array}{c}-0.068 \\
(0.047)\end{array}$ & $\begin{array}{c}0.055 \\
(0.036)\end{array}$ \\
\hline Number of Female Adults & $\begin{array}{c}0.006 \\
(0.011)\end{array}$ & $\begin{array}{c}0.028 \\
(0.067)\end{array}$ & $\begin{array}{c}0.045^{* * *} \\
(0.012)\end{array}$ & $\begin{array}{c}0.186^{* * *} \\
(0.064)\end{array}$ & $\begin{array}{c}0.145^{* * *} \\
(0.050)\end{array}$ \\
\hline Number of Children & $\begin{array}{c}0.040 * * * \\
(0.011)\end{array}$ & $\begin{array}{c}0.072 \\
(0.062)\end{array}$ & $\begin{array}{c}0.075 * * * \\
(0.010)\end{array}$ & $\begin{array}{l}0.108 * \\
(0.059)\end{array}$ & $\begin{array}{c}0.149 * * * \\
(0.048)\end{array}$ \\
\hline Number of Female Children & $\begin{array}{c}-0.010 \\
(0.008)\end{array}$ & $\begin{array}{l}-0.016 \\
(0.047)\end{array}$ & $\begin{array}{c}0.003 \\
(0.007)\end{array}$ & $\begin{array}{c}-0.001 \\
(0.039)\end{array}$ & $\begin{array}{c}0.039 \\
(0.038)\end{array}$ \\
\hline Number of Elderly & $\begin{array}{c}0.047 * * * \\
(0.014)\end{array}$ & $\begin{array}{c}0.261 * * * \\
(0.076)\end{array}$ & $\begin{array}{c}-0.085 * * * \\
(0.016)\end{array}$ & $\begin{array}{l}0.225 * * \\
(0.093)\end{array}$ & $\begin{array}{c}-0.360 * * * \\
(0.060)\end{array}$ \\
\hline Number of Female Elderly & $\begin{array}{c}0.024 \\
(0.017)\end{array}$ & $\begin{array}{l}-0.033 \\
(0.104)\end{array}$ & $\begin{array}{c}0.072 * * * \\
(0.019)\end{array}$ & $\begin{array}{l}-0.026 \\
(0.116)\end{array}$ & $\begin{array}{c}0.144 * * \\
(0.070)\end{array}$ \\
\hline Never Married / Divorced Hse & $\begin{array}{c}-0.040 * * * \\
(0.011)\end{array}$ & $\begin{array}{c}-0.261 * * * \\
(0.074)\end{array}$ & $\begin{array}{l}-0.017 \\
(0.011)\end{array}$ & $\begin{array}{c}-0.149 * * \\
(0.064)\end{array}$ & $\begin{array}{c}0.147 * * \\
(0.059)\end{array}$ \\
\hline Widowed Household & $\begin{array}{c}-0.040 * * * \\
(0.012)\end{array}$ & $\begin{array}{l}-0.138 * \\
(0.078)\end{array}$ & $\begin{array}{c}-0.064 * * * \\
(0.012)\end{array}$ & $\begin{array}{c}-0.299 * * * \\
(0.078)\end{array}$ & $\begin{array}{c}-0.155^{* * *} \\
(0.057)\end{array}$ \\
\hline Age of Youngest Child & $\begin{array}{c}0.000 \\
(0.001)\end{array}$ & $\begin{array}{c}0.002 \\
(0.004)\end{array}$ & $\begin{array}{c}0.000 \\
(0.001)\end{array}$ & $\begin{array}{l}0.007^{*} \\
(0.004)\end{array}$ & $\begin{array}{c}0.003 \\
(0.004)\end{array}$ \\
\hline Average Age of Adults & $\begin{array}{c}0.001^{* * *} \\
0.000\end{array}$ & $\begin{array}{c}0.007 * * * \\
(0.002)\end{array}$ & $\begin{array}{c}-0.003 * * * \\
0.000\end{array}$ & $\begin{array}{c}-0.005 * * * \\
(0.002)\end{array}$ & $\begin{array}{c}-0.014 * * * \\
(0.001)\end{array}$ \\
\hline Age of Oldest Elder & $\begin{array}{c}-0.001 * * * \\
0.000\end{array}$ & $\begin{array}{c}-0.003 * * \\
(0.002)\end{array}$ & $\begin{array}{c}-0.001 * * \\
0.000\end{array}$ & $\begin{array}{c}-0.008 * * * \\
(0.002)\end{array}$ & $\begin{array}{l}-0.002 * \\
(0.001)\end{array}$ \\
\hline Number Currently in School & $\begin{array}{c}-0.020 * * * \\
(0.007)\end{array}$ & $\begin{array}{c}-0.119 * * * \\
(0.043)\end{array}$ & $\begin{array}{c}-0.021 * * * \\
(0.007)\end{array}$ & $\begin{array}{l}-0.011 \\
(0.039)\end{array}$ & $\begin{array}{l}-0.029 \\
(0.034)\end{array}$ \\
\hline Number Currently in University & $\begin{array}{c}-0.025^{* *} \\
(0.013)\end{array}$ & $\begin{array}{c}-0.058 \\
(0.075)\end{array}$ & $\begin{array}{l}0.019^{*} \\
(0.011)\end{array}$ & $\begin{array}{c}0.222 * * * \\
(0.059)\end{array}$ & $\begin{array}{c}0.250 * * * \\
(0.062)\end{array}$ \\
\hline Number Completed Gen Sec Ed & $\begin{array}{l}0.010 * * \\
(0.005)\end{array}$ & $\begin{array}{c}-0.001 \\
(0.027)\end{array}$ & $\begin{array}{l}-0.005 \\
(0.005)\end{array}$ & $\begin{array}{c}0.126^{* * *} \\
(0.027)\end{array}$ & $\begin{array}{l}-0.025 \\
(0.022)\end{array}$ \\
\hline Number w/ University Diploma & $\begin{array}{c}0.030 * * * \\
(0.006)\end{array}$ & $\begin{array}{c}0.076 * * \\
(0.031)\end{array}$ & $\begin{array}{c}0.036 * * * \\
(0.006)\end{array}$ & $\begin{array}{c}0.103 * * * \\
(0.034)\end{array}$ & $\begin{array}{c}0.037 \\
(0.030)\end{array}$ \\
\hline Number w/ Professional Course & $\begin{array}{c}0.034 * * * \\
(0.005)\end{array}$ & $\begin{array}{c}-0.018 \\
(0.027)\end{array}$ & $\begin{array}{l}0.010 * \\
(0.005)\end{array}$ & $\begin{array}{c}-0.030 \\
(0.031)\end{array}$ & $\begin{array}{c}-0.069 * * * \\
(0.024)\end{array}$ \\
\hline $\begin{array}{l}\text { R-Squared } \\
\text { Households }\end{array}$ & 19022 & $\begin{array}{c}0.11 \\
4512\end{array}$ & 19066 & $\begin{array}{c}0.15 \\
4383\end{array}$ & $\begin{array}{c}0.13 \\
19113\end{array}$ \\
\hline
\end{tabular}

Note: Coefficients followed by 3, 2, and 1 star are significantly different from zero at the 1, 5, and 10 percent level, respectively. Marginal effects, evaluated at the sample mean, are presented for the logistic regression models in columns (1) and (3), while model coefficients are presented for the OLS regression models in columns (2), (4), and (5). All standard errors are estimated using the Huber/White method and allow for arbitrary correlation in an household's error term across years. Standard errors of the marginal effects are presented for the logistic regression models. All regressions also include year and community fixed effects. 
Table 5a: Estimated Covariates of Household Transfer Activity (Young Single Generation Households: Respondent $<35$ )

\begin{tabular}{|c|c|c|c|c|c|}
\hline Dependent Variable & $\begin{array}{c}\text { (1) } \\
\text { Gave } \\
\text { Transfers }\end{array}$ & $\begin{array}{c}\text { (2) } \\
\text { Log Amount } \\
\text { Given if Any }\end{array}$ & $\begin{array}{l}\text { (3) } \\
\text { Received } \\
\text { Transfers }\end{array}$ & $\begin{array}{c}\text { (4) } \\
\text { Log Amount } \\
\text { Received if Any }\end{array}$ & $\begin{array}{c}(5) \\
\text { Log Net } \\
\text { Transfers } \\
\text { Received }\end{array}$ \\
\hline Log Household Income & $\begin{array}{c}0.040 * * * \\
(0.006)\end{array}$ & $\begin{array}{c}0.194 * * * \\
(0.040)\end{array}$ & $\begin{array}{c}-0.099 * * * \\
(0.008)\end{array}$ & $\begin{array}{c}-0.172 * * * \\
(0.027)\end{array}$ & $\begin{array}{c}-0.551^{* * *} \\
(0.034)\end{array}$ \\
\hline Number of Household Members & $\begin{array}{c}-0.043 * * \\
(0.019)\end{array}$ & $\begin{array}{c}-0.108 \\
(0.124)\end{array}$ & $\begin{array}{c}-0.091 * * * \\
(0.027)\end{array}$ & $\begin{array}{l}-0.066 \\
(0.082)\end{array}$ & $\begin{array}{l}-0.170 \\
(0.105)\end{array}$ \\
\hline $\begin{array}{l}\text { Number of Female Adults } \\
\text { and Elderly }\end{array}$ & $\begin{array}{c}0.020 \\
(0.024)\end{array}$ & $\begin{array}{c}0.122 \\
(0.180)\end{array}$ & $\begin{array}{l}0.088^{* *} \\
(0.037)\end{array}$ & $\begin{array}{l}0.216^{* *} \\
(0.105)\end{array}$ & $\begin{array}{l}0.271^{*} \\
(0.141)\end{array}$ \\
\hline Number of Children & $\begin{array}{c}0.022 \\
(0.022)\end{array}$ & $\begin{array}{c}0.132 \\
(0.152)\end{array}$ & $\begin{array}{c}0.084 * * \\
(0.033)\end{array}$ & $\begin{array}{c}0.083 \\
(0.098)\end{array}$ & $\begin{array}{l}0.210^{*} \\
(0.124)\end{array}$ \\
\hline Number of Female Children & $\begin{array}{c}-0.002 \\
(0.013)\end{array}$ & $\begin{array}{l}-0.121 \\
(0.100)\end{array}$ & $\begin{array}{c}0.002 \\
(0.018)\end{array}$ & $\begin{array}{l}-0.046 \\
(0.058)\end{array}$ & $\begin{array}{l}-0.015 \\
(0.073)\end{array}$ \\
\hline Non-Married Household & $\begin{array}{c}0.022 \\
(0.023)\end{array}$ & $\begin{array}{l}-0.077 \\
(0.153)\end{array}$ & $\begin{array}{c}-0.108 * * * \\
(0.031)\end{array}$ & $\begin{array}{c}0.016 \\
(0.100)\end{array}$ & $\begin{array}{c}-0.333^{* * *} \\
(0.123)\end{array}$ \\
\hline Age of Youngest Child & $\begin{array}{c}0.003 \\
(0.002)\end{array}$ & $\begin{array}{c}0.002 \\
(0.012)\end{array}$ & $\begin{array}{c}-0.004 \\
(0.003)\end{array}$ & $\begin{array}{c}0.004 \\
(0.008)\end{array}$ & $\begin{array}{c}-0.019^{*} \\
(0.010)\end{array}$ \\
\hline Average Age of Adults & $\begin{array}{c}0.001 \\
(0.001)\end{array}$ & $\begin{array}{c}0.003 \\
(0.009)\end{array}$ & $\begin{array}{c}-0.013 * * * \\
(0.003)\end{array}$ & $\begin{array}{c}-0.019 * * * \\
(0.007)\end{array}$ & $\begin{array}{c}-0.052 * * * \\
(0.009)\end{array}$ \\
\hline Number Currently in School & $\begin{array}{l}-0.005 \\
(0.014)\end{array}$ & $\begin{array}{c}0.128 \\
(0.099)\end{array}$ & $\begin{array}{c}-0.002 \\
(0.020)\end{array}$ & $\begin{array}{c}0.026 \\
(0.065)\end{array}$ & $\begin{array}{l}-0.001 \\
(0.079)\end{array}$ \\
\hline Number Currently in University & $\begin{array}{c}0.013 \\
(0.024)\end{array}$ & $\begin{array}{l}-0.065 \\
(0.190)\end{array}$ & $\begin{array}{c}0.153 * * * \\
(0.037)\end{array}$ & $\begin{array}{c}0.282 * * * \\
(0.083)\end{array}$ & $\begin{array}{c}0.636 * * * \\
(0.142)\end{array}$ \\
\hline Number Completed Gen Sec Ed & $\begin{array}{c}0.006 \\
(0.010)\end{array}$ & $\begin{array}{c}0.083 \\
(0.069)\end{array}$ & $\begin{array}{l}-0.009 \\
(0.015)\end{array}$ & $\begin{array}{c}0.110 * * \\
(0.045)\end{array}$ & $\begin{array}{l}-0.002 \\
(0.057)\end{array}$ \\
\hline Number w/ University Diploma & $\begin{array}{l}0.022^{*} \\
(0.012)\end{array}$ & $\begin{array}{l}-0.061 \\
(0.082)\end{array}$ & $\begin{array}{c}0.078 * * * \\
(0.018)\end{array}$ & $\begin{array}{c}0.065 \\
(0.059)\end{array}$ & $\begin{array}{c}0.236 * * * \\
(0.072)\end{array}$ \\
\hline Number w/ Professional Course & $\begin{array}{c}0.030 * * * \\
(0.010)\end{array}$ & $\begin{array}{c}0.111 \\
(0.075)\end{array}$ & $\begin{array}{c}0.019 \\
(0.015)\end{array}$ & $\begin{array}{c}0.056 \\
(0.050)\end{array}$ & $\begin{array}{c}-0.028 \\
(0.061)\end{array}$ \\
\hline $\begin{array}{l}\text { R-Squared } \\
\text { Households }\end{array}$ & 3572 & $\begin{array}{l}0.16 \\
732\end{array}$ & 3695 & $\begin{array}{c}0.14 \\
1578\end{array}$ & $\begin{array}{l}0.17 \\
3706\end{array}$ \\
\hline $\begin{array}{l}\text { Note: Coefficients followed by } 3 \\
\text { respectively. Marginal effects, e } \\
\text { columns (1) and (3), while mode } \\
\text { (5). All standard errors are estim } \\
\text { household's error term across ye } \\
\text { models. All regressions also incl }\end{array}$ & ind 1 sta & sented for $\mathrm{t}$ & t from $z$ & $\begin{array}{l}\text { the } 1,5 \text {, and } \\
\text { ogistic regressi } \\
\text { models in colur }\end{array}$ & $\begin{array}{l}\text { ercent level, } \\
\text { nodels in } \\
\text { (2), (4), and } \\
\text { in an }\end{array}$ \\
\hline
\end{tabular}


Table 5b: Estimated Covariates of Household Transfer Activity (Older Single Generation Households w/ Children: Respondent 35 - 54)

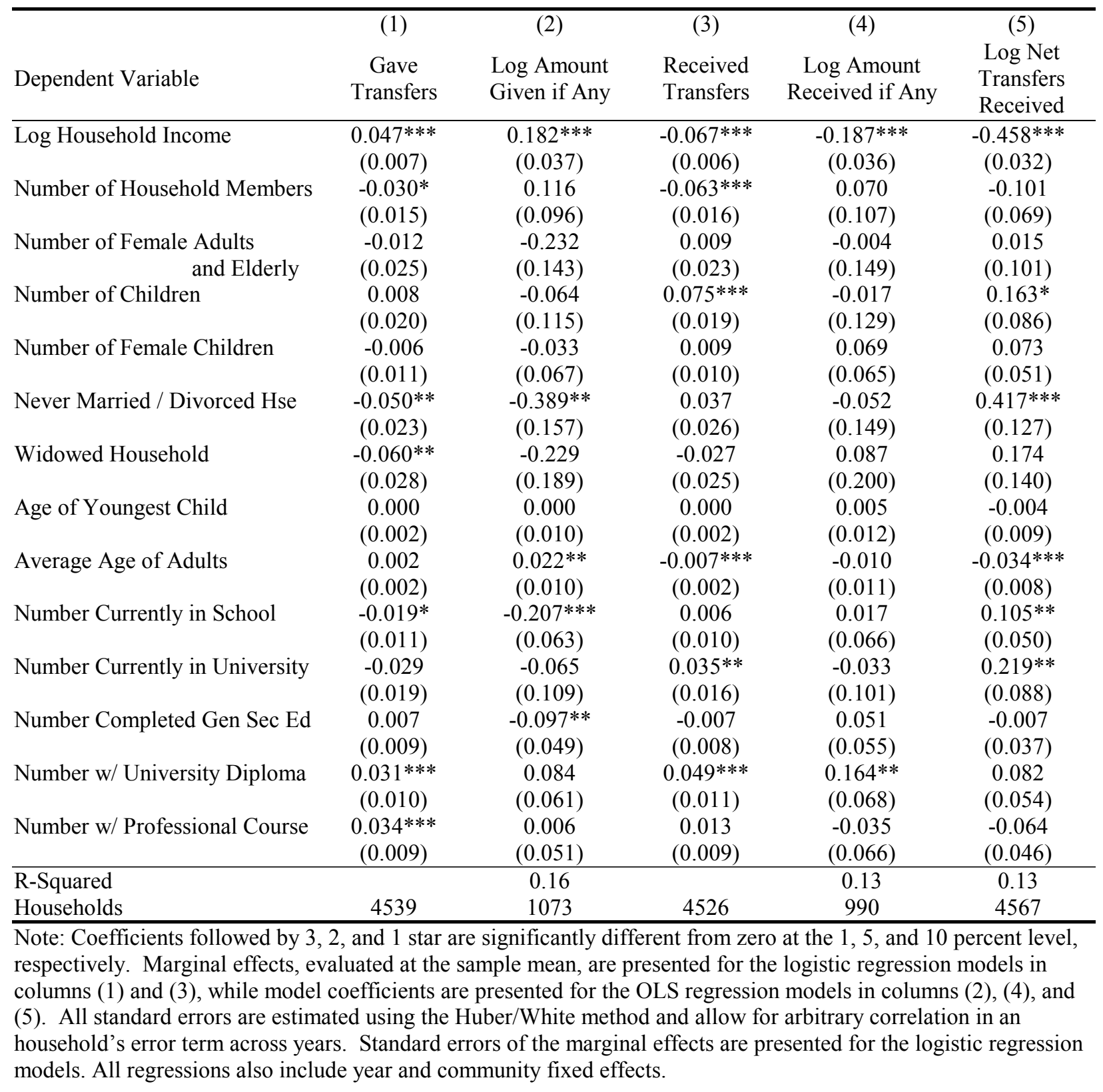


Table 5c: Estimated Covariates of Household Transfer Activity (Older Single Generation Households w/o Children: Respondent 35 - 54)

\begin{tabular}{|c|c|c|c|c|c|}
\hline & (1) & (2) & (3) & (4) & $(5)$ \\
\hline Dependent Variable & $\begin{array}{c}\text { Gave } \\
\text { Transfers }\end{array}$ & $\begin{array}{l}\text { Log Amount } \\
\text { Given if Any }\end{array}$ & $\begin{array}{l}\text { Received } \\
\text { Transfers }\end{array}$ & $\begin{array}{l}\text { Log Amount } \\
\text { Received if Any }\end{array}$ & $\begin{array}{c}\text { Log Net } \\
\text { Transfers } \\
\text { Received }\end{array}$ \\
\hline Log Household Income & $\begin{array}{c}0.102^{* * * *} \\
(0.012)\end{array}$ & $\begin{array}{c}0.203^{* * *} \\
(0.057)\end{array}$ & $\begin{array}{c}-0.055^{* * *} \\
(0.008)\end{array}$ & $\begin{array}{l}-0.085 \\
(0.073)\end{array}$ & $\begin{array}{c}-0.530 * * * \\
(0.048)\end{array}$ \\
\hline Number of Household Members & $\begin{array}{c}-0.134 * * * \\
(0.030)\end{array}$ & $\begin{array}{l}-0.106 \\
(0.155)\end{array}$ & $\begin{array}{l}-0.040^{*} \\
(0.022)\end{array}$ & $\begin{array}{c}-0.415^{* * * *} \\
(0.149)\end{array}$ & $\begin{array}{c}0.140 \\
(0.097)\end{array}$ \\
\hline $\begin{array}{l}\text { Number of Female Adults } \\
\text { and Elderly }\end{array}$ & $\begin{array}{c}0.039 \\
(0.031)\end{array}$ & $\begin{array}{l}-0.220 \\
(0.174)\end{array}$ & $\begin{array}{l}0.006 \\
(0.022)\end{array}$ & $\begin{array}{c}0.227 \\
(0.184)\end{array}$ & $\begin{array}{c}0.053 \\
(0.103)\end{array}$ \\
\hline Never Married / Divorced Hse & $\begin{array}{c}-0.112 * * * \\
(0.034)\end{array}$ & $\begin{array}{l}-0.379^{*} \\
(0.196)\end{array}$ & $\begin{array}{l}-0.008 \\
(0.030)\end{array}$ & $\begin{array}{c}-0.621 * * * \\
(0.210)\end{array}$ & $\begin{array}{l}0.287^{*} \\
(0.149)\end{array}$ \\
\hline Widowed Household & $\begin{array}{l}-0.053 \\
(0.042)\end{array}$ & $\begin{array}{l}-0.065 \\
(0.234)\end{array}$ & $\begin{array}{l}0.026 \\
(0.038)\end{array}$ & $\begin{array}{l}-0.284 \\
(0.237)\end{array}$ & $\begin{array}{c}0.227 \\
(0.179)\end{array}$ \\
\hline Average Age of Adults & $\begin{array}{c}0.009 * * * \\
(0.002)\end{array}$ & $\begin{array}{l}0.019^{*} \\
(0.011)\end{array}$ & $\begin{array}{c}-0.005 * * * \\
(0.002)\end{array}$ & $\begin{array}{c}-0.028 * * \\
(0.013)\end{array}$ & $\begin{array}{c}-0.049 * * * \\
(0.010)\end{array}$ \\
\hline Number Completed Gen Sec Ed & $\begin{array}{c}0.028 \\
(0.017)\end{array}$ & $\begin{array}{c}0.005 \\
(0.080)\end{array}$ & $\begin{array}{c}0.003 \\
(0.014)\end{array}$ & $\begin{array}{c}0.172 \\
(0.107)\end{array}$ & $\begin{array}{l}-0.025 \\
(0.060)\end{array}$ \\
\hline Number w/ University Diploma & $\begin{array}{l}0.049 * * \\
(0.021)\end{array}$ & $\begin{array}{c}0.065 \\
(0.087)\end{array}$ & $\begin{array}{c}0.001 \\
(0.018)\end{array}$ & $\begin{array}{c}0.179 \\
(0.139)\end{array}$ & $\begin{array}{l}-0.105 \\
(0.083)\end{array}$ \\
\hline Number w/ Professional Course & $\begin{array}{c}0.048 * * * \\
(0.019)\end{array}$ & $\begin{array}{c}0.067 \\
(0.074)\end{array}$ & $\begin{array}{c}0.015 \\
(0.013)\end{array}$ & $\begin{array}{l}-0.008 \\
(0.114)\end{array}$ & $\begin{array}{l}-0.083 \\
(0.068)\end{array}$ \\
\hline $\begin{array}{l}\text { R-Squared } \\
\text { Households }\end{array}$ & 1919 & $\begin{array}{c}0.16 \\
610\end{array}$ & 1891 & $\begin{array}{l}0.20 \\
345\end{array}$ & $\begin{array}{l}0.17 \\
1949\end{array}$ \\
\hline
\end{tabular}

Note: Coefficients followed by 3,2, and 1 star are significantly different from zero at the 1, 5, and 10 percent level, respectively. Marginal effects, evaluated at the sample mean, are presented for the logistic regression models in columns (1) and (3), while model coefficients are presented for the OLS regression models in columns (2), (4), and (5). All standard errors are estimated using the Huber/White method and allow for arbitrary correlation in an household's error term across years. Standard errors of the marginal effects are presented for the logistic regression models. All regressions also include year and community fixed effects. 
Table 5d: Estimated Covariates of Household Transfer Activity (Elderly Single Generation Households: Respondent > 54)

\begin{tabular}{|c|c|c|c|c|c|}
\hline Dependent Variable & $\begin{array}{c}\text { (1) } \\
\text { Gave } \\
\text { Transfers }\end{array}$ & $\begin{array}{c}\text { (2) } \\
\text { Log Amount } \\
\text { Given if Any }\end{array}$ & $\begin{array}{c}\text { (3) } \\
\text { Received } \\
\text { Transfers }\end{array}$ & $\begin{array}{c}\text { (4) } \\
\text { Log Amount } \\
\text { Received if Any }\end{array}$ & $\begin{array}{c}(5) \\
\text { Log Net } \\
\text { Transfers } \\
\text { Received }\end{array}$ \\
\hline Log Household Income & $\begin{array}{c}0.090^{* * *} \\
(0.009)\end{array}$ & $\begin{array}{c}0.292 * * * \\
(0.047)\end{array}$ & $\begin{array}{c}-0.070^{* * *} \\
(0.006)\end{array}$ & $\begin{array}{l}-0.279 * * * \\
(0.054)\end{array}$ & $\begin{array}{l}-0.568 * * * \\
(0.036)\end{array}$ \\
\hline $\begin{array}{l}\text { Additional Adults or Elderly } \\
\text { in the Household }\end{array}$ & $\begin{array}{l}-0.100 * * * \\
(0.025)\end{array}$ & $\begin{array}{c}0.027 \\
(0.207)\end{array}$ & $\begin{array}{l}-0.015 \\
(0.033)\end{array}$ & $\begin{array}{l}-0.402 \\
(0.279)\end{array}$ & $\begin{array}{c}0.260^{* *} \\
(0.132)\end{array}$ \\
\hline $\begin{array}{l}\text { Additional Female Adults or } \\
\text { Elderly in the Hse }\end{array}$ & $\begin{array}{c}0.005 \\
(0.032)\end{array}$ & $\begin{array}{l}-0.066 \\
(0.177)\end{array}$ & $\begin{array}{l}-0.012 \\
(0.024)\end{array}$ & $\begin{array}{c}0.247 \\
(0.214)\end{array}$ & $\begin{array}{l}-0.014 \\
(0.111)\end{array}$ \\
\hline Any Children in the Household & $\begin{array}{c}-0.059 * * * \\
(0.020)\end{array}$ & $\begin{array}{c}0.154 \\
(0.119)\end{array}$ & $\begin{array}{c}0.035 \\
(0.022)\end{array}$ & $\begin{array}{l}0.273^{*} \\
(0.149)\end{array}$ & $\begin{array}{c}0.284 * * * \\
(0.098)\end{array}$ \\
\hline Never Married / Divorced Hse & $\begin{array}{l}-0.027 \\
(0.022)\end{array}$ & $\begin{array}{c}-0.262 * * \\
(0.129)\end{array}$ & $\begin{array}{c}0.013 \\
(0.019)\end{array}$ & $\begin{array}{l}-0.622 * * * \\
(0.152)\end{array}$ & $\begin{array}{c}0.111 \\
(0.092)\end{array}$ \\
\hline Widowed Household & $\begin{array}{c}-0.035^{* *} \\
(0.017)\end{array}$ & $\begin{array}{c}-0.274 * * * \\
(0.086)\end{array}$ & $\begin{array}{l}0.031^{* *} \\
(0.013)\end{array}$ & $\begin{array}{c}-0.564 * * * \\
(0.117)\end{array}$ & $\begin{array}{c}0.186^{* * *} \\
(0.065)\end{array}$ \\
\hline Average Age of Adults & $\begin{array}{l}-0.001 \\
(0.000)\end{array}$ & $\begin{array}{c}0.001 \\
(0.002)\end{array}$ & $\begin{array}{c}0.000 \\
(0.000)\end{array}$ & $\begin{array}{l}-0.005 \\
(0.003)\end{array}$ & $\begin{array}{c}0.000 \\
(0.001)\end{array}$ \\
\hline Age of Oldest Elder & $\begin{array}{c}-0.001 * * \\
(0.001)\end{array}$ & $\begin{array}{l}0.000 \\
(0.003)\end{array}$ & $\begin{array}{c}0.000 \\
(0.000)\end{array}$ & $\begin{array}{l}-0.003 \\
(0.004)\end{array}$ & $\begin{array}{l}0.004 * \\
(0.002)\end{array}$ \\
\hline Number Completed Gen Sec Ed & $\begin{array}{c}0.006 \\
(0.012)\end{array}$ & $\begin{array}{l}-0.034 \\
(0.064)\end{array}$ & $\begin{array}{c}0.006 \\
(0.010)\end{array}$ & $\begin{array}{c}0.264 * * * \\
(0.071)\end{array}$ & $\begin{array}{c}0.050 \\
(0.049)\end{array}$ \\
\hline Number w/ University Diploma & $\begin{array}{c}0.060 * * * \\
(0.016)\end{array}$ & $\begin{array}{c}0.267 * * * \\
(0.082)\end{array}$ & $\begin{array}{l}0.039 * * * \\
(0.014)\end{array}$ & $\begin{array}{c}0.124 \\
(0.094)\end{array}$ & $\begin{array}{l}-0.103 \\
(0.083)\end{array}$ \\
\hline Number w/ Professional Course & $\begin{array}{l}0.021^{*} \\
(0.012)\end{array}$ & $\begin{array}{l}-0.095^{*} \\
(0.058)\end{array}$ & $\begin{array}{l}0.017^{*} \\
(0.010)\end{array}$ & $\begin{array}{c}-0.034 \\
(0.082)\end{array}$ & $\begin{array}{c}0.025 \\
(0.047)\end{array}$ \\
\hline R-Squared & & 0.18 & & 0.22 & 0.12 \\
\hline Households & 5682 & 1422 & 5680 & 970 & 5726 \\
\hline
\end{tabular}


Table 6: Estimated Effects of Household Income/Pension on Household Transfer Activity

\begin{tabular}{|c|c|c|c|c|c|}
\hline Dependent Variable & $\begin{array}{c}\text { Gave } \\
\text { Transfers }\end{array}$ & $\begin{array}{l}\text { Log Amount } \\
\text { Given if Any }\end{array}$ & $\begin{array}{l}\text { Received } \\
\text { Transfers }\end{array}$ & $\begin{array}{l}\text { Log Amount } \\
\text { Received if Any }\end{array}$ & $\begin{array}{c}(5) \\
\text { Log Net } \\
\text { Transfers } \\
\text { Received }\end{array}$ \\
\hline \multicolumn{6}{|c|}{ All Households Pooled } \\
\hline Log Household Income & $\begin{array}{c}0.061 * * * \\
(0.004)\end{array}$ & $\begin{array}{c}0.216^{* * *} \\
(0.021)\end{array}$ & $\begin{array}{c}-0.066^{* * * *} \\
(0.003)\end{array}$ & $\begin{array}{c}-0.174 * * * \\
(0.018)\end{array}$ & $\begin{array}{c}-0.503 * * * \\
(0.017)\end{array}$ \\
\hline Log Permanent Hse Income & $\begin{array}{c}0.089 * * * \\
(0.005)\end{array}$ & $\begin{array}{c}0.305 * * * \\
(0.031)\end{array}$ & $\begin{array}{c}-0.079^{* * *} \\
(0.005)\end{array}$ & $\begin{array}{c}-0.086^{* * *} \\
(0.025)\end{array}$ & $\begin{array}{c}-0.636^{* * * *} \\
(0.026)\end{array}$ \\
\hline Log Transitory Hse Income & $\begin{array}{c}0.035^{* * *} \\
(0.004)\end{array}$ & $\begin{array}{c}0.140^{* * *} \\
(0.024)\end{array}$ & $\begin{array}{c}-0.055^{* * *} \\
(0.004)\end{array}$ & $\begin{array}{c}-0.250^{* * *} \\
(0.024)\end{array}$ & $\begin{array}{c}-0.393 * * * \\
(0.020)\end{array}$ \\
\hline \multicolumn{6}{|c|}{ Young Single Generation Households: Respondent $<35$} \\
\hline Log Household Income & $\begin{array}{c}0.040 * * * \\
(0.006)\end{array}$ & $\begin{array}{c}0.194^{* * *} \\
(0.040)\end{array}$ & $\begin{array}{c}-0.099 * * * \\
(0.008)\end{array}$ & $\begin{array}{c}-0.172 * * * \\
(0.027)\end{array}$ & $\begin{array}{c}-0.551^{* * *} \\
(0.034)\end{array}$ \\
\hline Log Permanent Hse Income & $\begin{array}{c}0.059 * * * \\
(0.008)\end{array}$ & $\begin{array}{c}0.327 * * * \\
(0.055)\end{array}$ & $\begin{array}{c}-0.113 * * * \\
(0.012)\end{array}$ & $\begin{array}{c}-0.141^{* * * *} \\
(0.035)\end{array}$ & $\begin{array}{c}-0.667 * * * \\
(0.047)\end{array}$ \\
\hline Log Transitory Hse Income & $\begin{array}{r}0.018^{* *} \\
(0.008) \\
\end{array}$ & $\begin{array}{c}0.035 \\
(0.058) \\
\end{array}$ & $\begin{array}{c}-0.084 * * * \\
(0.010) \\
\end{array}$ & $\begin{array}{c}-0.207^{* * *} \\
(0.039) \\
\end{array}$ & $\begin{array}{c}-0.428^{* * *} \\
(0.045)\end{array}$ \\
\hline \multicolumn{6}{|c|}{ Older Single Generation Households w/ Children: Respondent 35 - 54} \\
\hline Log Household Income & $\begin{array}{c}0.047 * * * \\
(0.007)\end{array}$ & $\begin{array}{c}0.182^{* * *} \\
(0.037)\end{array}$ & $\begin{array}{c}-0.067 * * * \\
(0.006)\end{array}$ & $\begin{array}{c}-0.187 * * * \\
(0.036)\end{array}$ & $\begin{array}{c}-0.458^{* * * *} \\
(0.032)\end{array}$ \\
\hline Log Permanent Hse Income & $\begin{array}{c}0.064 * * * \\
(0.011)\end{array}$ & $\begin{array}{c}0.287 * * * \\
(0.061)\end{array}$ & $\begin{array}{c}-0.089^{* * *} \\
(0.010)\end{array}$ & $\begin{array}{l}-0.033 \\
(0.061)\end{array}$ & $\begin{array}{c}-0.565^{* * *} \\
(0.050)\end{array}$ \\
\hline Log Transitory Hse Income & $\begin{array}{c}0.034 * * * \\
(0.008)\end{array}$ & $\begin{array}{c}0.109^{* * *} \\
(0.041) \\
\end{array}$ & $\begin{array}{c}-0.052^{* * *} \\
(0.006)\end{array}$ & $\begin{array}{c}-0.279^{* * *} \\
(0.042) \\
\end{array}$ & $\begin{array}{c}-0.383 * * * \\
(0.038)\end{array}$ \\
\hline \multicolumn{6}{|c|}{$\begin{array}{c}\text { Older Single Generation Households w/o Children: Respondent } 35-54 \\
\end{array}$} \\
\hline Log Household Income & $\begin{array}{c}0.102 * * * \\
(0.012)\end{array}$ & $\begin{array}{c}0.203 * * * \\
(0.057)\end{array}$ & $\begin{array}{c}-0.055^{* * *} \\
(0.008)\end{array}$ & $\begin{array}{c}-0.085 \\
(0.073) \\
\end{array}$ & $\begin{array}{c}-0.530 * * * \\
(0.048)\end{array}$ \\
\hline Log Permanent Hse Income & $\begin{array}{c}0.128 * * * \\
(0.017)\end{array}$ & $\begin{array}{c}0.225^{* * *} \\
(0.082)\end{array}$ & $\begin{array}{c}-0.072 * * * \\
(0.012)\end{array}$ & $\begin{array}{l}-0.007 \\
(0.093)\end{array}$ & $\begin{array}{c}-0.651^{* * * *} \\
(0.063)\end{array}$ \\
\hline Log Transitory Hse Income & $\begin{array}{c}0.074 * * * \\
(0.016)\end{array}$ & $\begin{array}{c}0.183 * * \\
(0.071)\end{array}$ & $\begin{array}{c}-0.038 * * * \\
(0.010)\end{array}$ & $\begin{array}{r}-0.148 \\
(0.097) \\
\end{array}$ & $\begin{array}{c}-0.407 * * * \\
(0.066)\end{array}$ \\
\hline \multirow{2}{*}{ Log Household Income } & Elderly Sing & $\frac{\text { heration Hou }}{0292 * * *}$ & ds: Respond & $\frac{54}{-0.279^{* * *}}$ & $-0.568 * * *$ \\
\hline & $(0.009)$ & $(0.047)$ & $(0.006)$ & $(0.054)$ & $(0.036)$ \\
\hline Log Permanent Hse Income & $\begin{array}{c}0.144 * * * \\
(0.014)\end{array}$ & $\begin{array}{c}0.431 * * * \\
(0.071)\end{array}$ & $\begin{array}{c}-0.084 * * * \\
(0.011)\end{array}$ & $\begin{array}{l}-0.103 \\
(0.083)\end{array}$ & $\begin{array}{c}-0.749 * * * \\
(0.057)\end{array}$ \\
\hline Log Transitory Hse Income & $\begin{array}{c}0.052 * * * \\
(0.010)\end{array}$ & $\begin{array}{c}0.196 * * * \\
(0.052)\end{array}$ & $\begin{array}{c}-0.062^{* * * *} \\
(0.007)\end{array}$ & $\begin{array}{c}-0.381^{* * * *} \\
(0.067)\end{array}$ & $\begin{array}{c}-0.454 * * * \\
(0.040)\end{array}$ \\
\hline Log Pension Income & $\begin{array}{c}0.068 * * * \\
(0.013)\end{array}$ & $\begin{array}{c}0.233 * * * \\
(0.070)\end{array}$ & $\begin{array}{c}-0.033 * * * \\
(0.010) \\
\end{array}$ & $\begin{array}{c}0.099 \\
(0.086)\end{array}$ & $\begin{array}{c}-0.311 * * * \\
(0.051)\end{array}$ \\
\hline Log Permanent Pension Inc & $\begin{array}{c}0.102 * * * \\
(0.019)\end{array}$ & $\begin{array}{l}0.223 * * \\
(0.101)\end{array}$ & $\begin{array}{c}-0.059^{* * *} \\
(0.016)\end{array}$ & $\begin{array}{c}0.122 \\
(0.122)\end{array}$ & $\begin{array}{c}-0.449 * * * \\
(0.079)\end{array}$ \\
\hline Log Transitory Pension Inc & $\begin{array}{c}0.041 * * * \\
(0.014) \\
\end{array}$ & $\begin{array}{c}0.240^{* * * *} \\
(0.081)\end{array}$ & $\begin{array}{c}-0.013 \\
(0.012) \\
\end{array}$ & $\begin{array}{c}0.081 \\
(0.104) \\
\end{array}$ & $\begin{array}{c}-0.206 * * * \\
(0.060)\end{array}$ \\
\hline $\begin{array}{l}\text { Note: Coefficients followed b } \\
\text { respectively. Marginal effect } \\
\text { columns (1) and (3), while m } \\
\text { (5). All standard errors are e } \\
\text { household's error term across } \\
\text { models. All regressions also }\end{array}$ & $\begin{array}{l}, 2 \text {, and } 1 \text {. } \\
\text { valuated a } \\
\text { coefficie } \\
\text { nated using } \\
\text { ars. Stand }\end{array}$ & $\begin{array}{l}\text { e significantl } \\
\text { sample mean, } \\
\text { e presented fo } \\
\text { Huber/White } r \\
\text { rors of the ma }\end{array}$ & $\begin{array}{l}\text { ferent from } \\
\text { resented for } \\
\text { OLS regres } \\
\text { od and allow } \\
\text { al effects ar }\end{array}$ & $\begin{array}{l}\text { at the } 1,5 \text {, and } \\
\text { logistic regressi } \\
\text { models in colun } \\
\text { arbitrary correl } \\
\text { esented for the lo }\end{array}$ & $\begin{array}{l}\text { ercent level, } \\
\text { lodels in } \\
(2),(4) \text {, and } \\
\text { in an } \\
\text { ic regression }\end{array}$ \\
\hline
\end{tabular}




\section{IZA Discussion Papers}

\begin{tabular}{|c|c|c|c|c|}
\hline No. & Author(s) & Title & Area & Date \\
\hline 559 & $\begin{array}{l}\text { B. R. Chiswick } \\
\text { T. J. Hatton }\end{array}$ & $\begin{array}{l}\text { International Migration and the Integration of } \\
\text { Labor Markets }\end{array}$ & 2 & 08/02 \\
\hline 560 & $\begin{array}{l}\text { J. W. Budd } \\
\text { J. Konings } \\
\text { M. J. Slaughter }\end{array}$ & $\begin{array}{l}\text { Wages and International Rent Sharing in } \\
\text { Multinational Firms }\end{array}$ & 2 & $08 / 02$ \\
\hline 561 & $\begin{array}{l}\text { W. J. Carrington } \\
\text { P. R. Mueser } \\
\text { K. R. Troske }\end{array}$ & $\begin{array}{l}\text { The Impact of Welfare Reform on Leaver } \\
\text { Characteristics, Employment and Recidivism }\end{array}$ & 3 & $08 / 02$ \\
\hline 562 & $\begin{array}{l}\text { J. T. Addison } \\
\text { W. S. Siebert }\end{array}$ & Changes in Collective Bargaining in the U.K. & 3 & $08 / 02$ \\
\hline 563 & $\begin{array}{l}\text { T. Dunne } \\
\text { L. Foster } \\
\text { J. Haltiwanger } \\
\text { K. R. Troske }\end{array}$ & $\begin{array}{l}\text { Wage and Productivity Dispersion in U.S. } \\
\text { Manufacturing: The Role of Computer } \\
\text { Investment }\end{array}$ & 5 & $08 / 02$ \\
\hline 564 & $\begin{array}{l}\text { J. D. Brown } \\
\text { J. S. Earle }\end{array}$ & $\begin{array}{l}\text { The Reallocation of Workers and Jobs in } \\
\text { Russian Industry: New Evidence on Measures } \\
\text { and Determinants }\end{array}$ & 4 & 09/02 \\
\hline 565 & $\begin{array}{l}\text { H. L. van Kranenburg } \\
\text { F. C. Palm } \\
\text { G. A. Pfann }\end{array}$ & $\begin{array}{l}\text { Survival in a Concentrating Industry: The Case } \\
\text { of Daily Newspapers in the Netherlands }\end{array}$ & 3 & $09 / 02$ \\
\hline 566 & $\begin{array}{l}\text { R. Hujer } \\
\text { M. Caliendo } \\
\text { D. Radić }\end{array}$ & $\begin{array}{l}\text { Skill Biased Technological and Organizational } \\
\text { Change: Estimating a Mixed Simultaneous } \\
\text { Equation Model Using the IAB Establishment } \\
\text { Panel }\end{array}$ & 5 & 09/02 \\
\hline 567 & $\begin{array}{l}\text { H. Lehmann } \\
\text { K. Phillips } \\
\text { J. Wadsworth }\end{array}$ & $\begin{array}{l}\text { The Incidence and Cost of Job Loss in a } \\
\text { Transition Economy: Displaced Workers in } \\
\text { Estonia, 1989-1999 }\end{array}$ & 4 & $09 / 02$ \\
\hline 568 & $\begin{array}{l}\text { H. O. Duleep } \\
\text { D. J. Dowhan }\end{array}$ & $\begin{array}{l}\text { Revisiting the Family Investment Model with } \\
\text { Longitudinal Data: The Earnings Growth of } \\
\text { Immigrant and U.S.-Born Women }\end{array}$ & 1 & 09/02 \\
\hline 569 & $\begin{array}{l}\text { J. Haltiwanger } \\
\text { M. Vodopivec }\end{array}$ & $\begin{array}{l}\text { Worker Flows, Job Flows and Firm Wage } \\
\text { Policies: An Analysis of Slovenia }\end{array}$ & 4 & $09 / 02$ \\
\hline 570 & $\begin{array}{l}\text { T. K. Bauer } \\
\text { S. Bender }\end{array}$ & $\begin{array}{l}\text { Technological Change, Organizational } \\
\text { Change, and Job Turnover }\end{array}$ & 1 & 09/02 \\
\hline 571 & $\begin{array}{l}\text { O. Ashenfelter } \\
\text { M. Greenstone }\end{array}$ & $\begin{array}{l}\text { Using Mandated Speed Limits to Measure the } \\
\text { Value of a Statistical Life }\end{array}$ & 5 & 09/02 \\
\hline 572 & $\begin{array}{l}\text { C. Y. Co } \\
\text { I. N. Gang } \\
\text { M.-S. Yun }\end{array}$ & $\begin{array}{l}\text { Self-Employment and Wage Earning: } \\
\text { Hungary During Transition }\end{array}$ & 4 & 09/02 \\
\hline 573 & $\begin{array}{l}\text { R. T. Riphahn } \\
\text { O. Serfling }\end{array}$ & $\begin{array}{l}\text { Item Non-Response on Income and Wealth } \\
\text { Questions }\end{array}$ & 6 & $09 / 02$ \\
\hline 574 & $\begin{array}{l}\text { R. Kuhn } \\
\text { S. Stillman }\end{array}$ & $\begin{array}{l}\text { Understanding Interhousehold Transfers in a } \\
\text { Transition Economy: Evidence from Russia }\end{array}$ & 4 & $09 / 02$ \\
\hline
\end{tabular}

An updated list of IZA Discussion Papers is available on the center's homepage www.iza.org. 